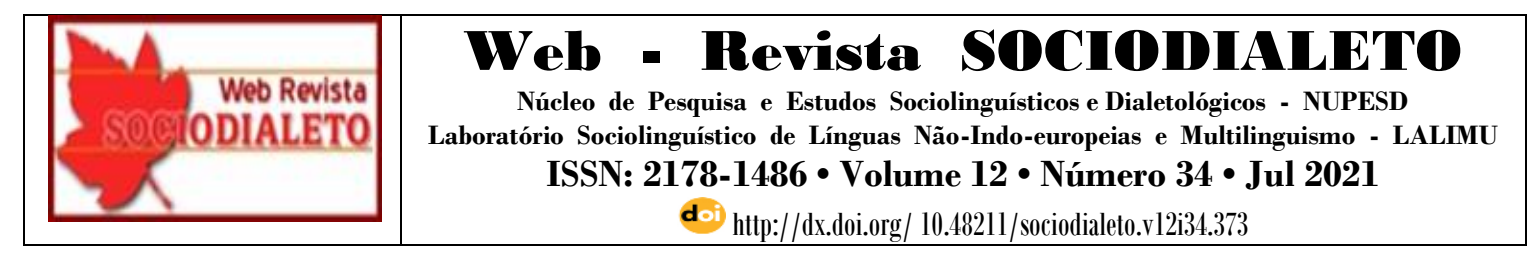

\title{
REFLEXÕES DE ORDEM SOCIOLINGUÍSTICA: RELAÇÕES ENTRE A ALFABETIZAÇÃO E O SISTEMA FONOLÓGICO E O SISTEMA ORTOGRÁFICO. VARIAÇÃ̃O E MUDANÇA
}

\section{REFLECTIONS OF SOCIOLINGUISTIC ORDER: RELATIONS BETWEEN LITERACY AND THE PHONOLOGICAL SYSTEM AND THE ORTHOGRAPHIC SYSTEM. VARIATION AND CHANGE}

\author{
César Costa Vitorino (MPIES-UNEB/FVC) ${ }^{1}$ \\ vitorinoleitura66@gmail.com
}

\author{
Constância Maria Borges de Souza (UNEB)² \\ csouza@uneb.br
}
Cristina Barreto Santos da Silva (MPIES-UNEB) ${ }^{3}$ cristinabarretosantos@gmail.com

\begin{abstract}
RESUMO: Neste trabalho, pretende-se, através de uma pesquisa bibliográfica, apresentar algumas considerações sobre o processo de Alfabetização, seus principais representantes e propostas para alfabetizar tanto crianças quanto adultos. Destaca-se a relação entre Sociolinguística e Alfabetização, observando a necessidade de mostrar a diferença da língua falada para língua escrita, sistema fonológico para sistema ortográfico, objetivando sucesso na aplicação das estratégias selecionadas, uma vez que o objetivo principal é habilitar os falantes no uso das variedades linguísticas e usá-las adequadamente tanto na modalidade oral quanto na escrita. Reforça-se a ideia de que as línguas só existem através de seus usuários (o povo) e a história desse povo determina a história dessa língua, na identidade dessa comunidade linguística. À luz da Sociolinguística Variacionista são apresentados e comentados os resultados de pesquisa com trinta informantes (F I - 7 a 14 anos; F II - 15 a 25 anos; F III - 26 a 35 anos) em uma comunidade rural baiana para evidenciar a ocorrência dos fenômenos linguísticos: semivocalização da consoante lateral palatal / $/ \mathrm{K}$; rotacismo nos grupos consonantais; monotongação de /ey/ e /ow/; síncope nas palavras proparoxítonas e semivocalização do /l/ em posição final de sílaba que podem ajudar no entendimento das relações entre o sistema fonológico e o sistema ortográfico de alfabetização inicial. Apresentam-se principais características dos comportamentos da fala relacionados aos níveis: sintático-semântico, lexical e sintático. Ressalta-se que a proposta de isomorfia parcial entre a fala e a escrita traz implicações pedagógicas para a alfabetização. Esclarece a respeito das principais características da escrita ideográfica, escrita fonográfica, escrita silábica, escrita consonantal, escrita fonética e escrita alfabética ortográfica. Por fim, enfatiza-se que, à medida que se faz o estudo sincrônico da língua, o pesquisador constata que as variações são permitidas pelas regras subjacentes à estrutura/sistema linguístico, que funciona como salvaguarda da manutenção da língua.
\end{abstract}

\footnotetext{
${ }^{1}$ Professor Permanente do MPIES - Mestrado Profissional em Intervenção Educativa e Social / Universidade do Estado da Bahia (UNEB). Professor lotado no Colegiado de Letras Vernáculas, DCH I, Salvador-Bahia / UNEB. Membro do Grupo de Pesquisa EPODS - Grupo de Pesquisa Educação, Políticas Públicas e Desenvolvimento Social. Membro do Grupo de Pesquisa NGEALC - Núcleo do Grupo de Estudos Africanos e Afro-brasileiros em Línguas e Culturas. Membro do Grupo de Pesquisa GCONPORT - Fala e contexto no português brasileiro / UNEB. Docente do Curso de Pedagogia da FVC - Fundação Visconde de Cairu.

${ }^{2}$ GCONPORT - Fala e contexto no português brasileiro / Universidade do Estado da Bahia.

${ }^{3}$ Mestranda do MPIES - Mestrado Profissional em Intervenção Educativa e Social / Universidade do Estado da Bahia, linha de pesquisa 1 - Novos Contextos de Aprendizagem.
} 


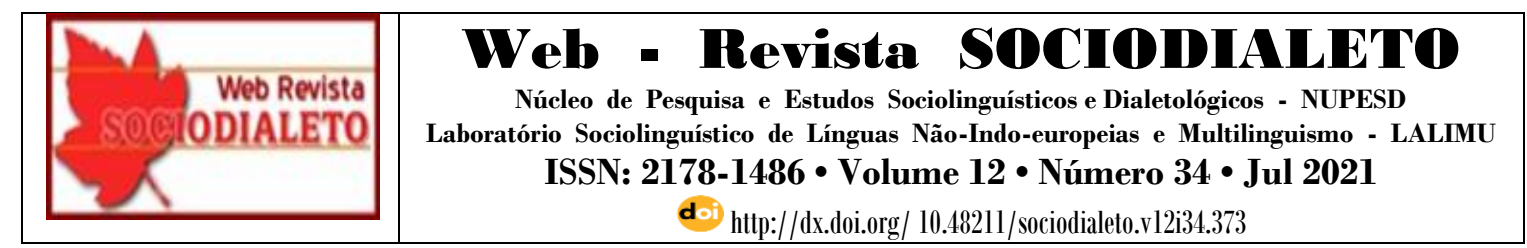

PALAVRAS-CHAVE: Alfabetização; Sociolinguística; Sistema fonológico; Sistema ortográfico; Pesquisa bibliográfica.

\begin{abstract}
In this work, it is intended, through a bibliographic search, to present some considerations about the Literacy process, its main representatives and proposals to literate both children and adults. The relationship between Sociolinguistics and Literacy stands out, noting the need to show the difference between spoken language and written language, phonological system andorthographic system, aiming at success in the application of the selected strategies, since the main objective is to enable speakers to the use of linguistic varieties and to use them properly in both oral and written forms. It reinforces the idea that languages exist only through their users (the people) and the history of that people determines the history of that language, in the identity of this linguistic community. In the light of Variationist Sociolinguistics, the results of a survey of thirty informants (FI - 7 to 14 years old; F II - 15 to 25 years old; F III - 26 to 35 years old) are presented and commented in a rural community in Bahia to evidence the occurrence of linguistic phenomena: semi vocalization of the palatal lateral consonant $/ \Lambda /$; rotacism in consonant groups; monophtongation of / ey / and / ow /; syncope in proparoxytone words and semi vocalization of / / / in the final position of syllable, that can help in understanding the relationships between the phonological system and the orthographic system of initial literacy. Main characteristics of speech behaviors related to syntacticsemantic, lexical and syntactic levels are presented. It is noteworthy that the proposal for partial isomorphism between speech and writing has pedagogical implications for literacy. It clarifies the main characteristics of ideographic writing, phonographic writing, syllabic writing, consonant writing, phonetic writing and orthographic alphabetical writing. Finally, it is emphasized that, as the synchronic study of the language is carried out, the researcher finds that variations are allowed by the rules underlying the linguistic structure/system, which functions as a safeguard for the maintenance of the language.
\end{abstract}

KEYWORDS: Literacy; Sociolinguistics; Phonological system; Orthographic system; Bibliographic research.

\title{
INTRODUÇÃO
}

Através dos posicionamentos de vários autores, tecemos algumas considerações sobre alfabetização, especificamente a relação entre sociolinguística e alfabetização. Nesse sentido, o objetivo dessa produção acadêmica consiste em refletir sobre as contribuições da Sociolinguística para o processo de alfabetização de crianças e adultos. O entendimento e a utilização do sistema linguístico tem como objetivo capacitar o indivíduo para compreender e ser compreendido na sociedade, podendo dela participar, conhecendo seus direitos e deveres, permitindo-lhes o acesso à escola, tendo o conhecimento da norma padrão e de suas variedades. Procuramos introduzir os pressupostos linguísticos pelos usos que caracterizam nossas práticas acadêmicas para melhor compreensão de nossos posicionamentos. A opção pela pesquisa bibliográfica deve-se ao fato de que através dela faz-se a revisão da literatura sobre as principais teorias 


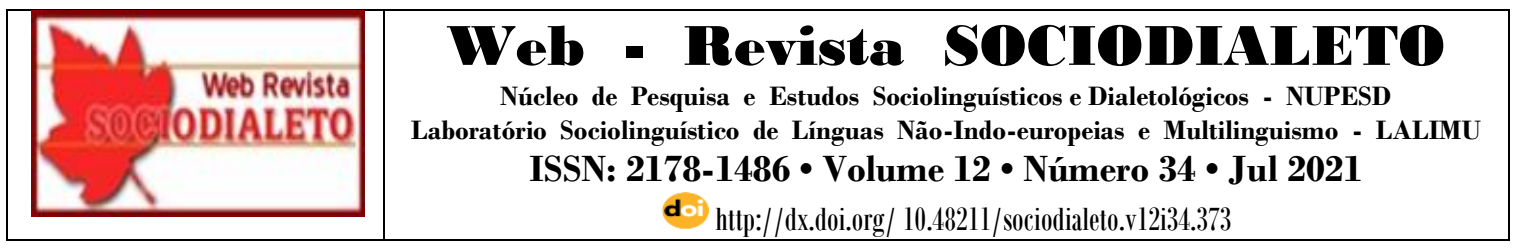

que norteiam sobre a temática desejada e pode ser realizada em livros, periódicos, artigo de jornais, sites da internet entre outras fontes.

Foi com Labov (1966) que as pesquisas sociolinguísticas tomaram novo impulso quando, ao combinar a análise estrutural das formas faladas com modernas técnicas sociológicas, viabilizaram-se métodos para traçar o caminho da difusão linguística e para relacionar as variáveis linguísticas com variáveis sociais. Um novo paradigma foi desenvolvido, rejeitando a noção estruturalista e gerativista da uniformidade do sistema gramatical. Para dar conta dos fatos empíricos da diversidade da fala, a teoria distinguiu entre variações individuais e variabilidade social. A variabilidade social é vista como uma propriedade inerente do sistema linguístico, a qual deve ser incorporada às regras gramaticais. Labov conceituou como "comunidade de fala" um grupo de pessoas que manifestam as mesmas normas de avaliação com referência a características da língua que falam. O foco de investigação volta-se para os fatores extralinguísticos, considerando-se uma comunidade de fala tanto uma entidade social quanto linguística.

Os trabalhos de Labov no campo da Sociolinguística datam das décadas de sessenta a oitenta (século XX). Pode-se dizer que seguem uma orientação antisaussuriana, ou seja, contrária à corrente dominante que deu origem ao Cours de Linguistique Générale. Assim, ao invés da langue, como fez Saussure, Labov centra os seus estudos na parole. E, ainda, opondo-se ao mestre de Genebra, enfoca o estudo da parole de um ponto de vista social e não individual.

Segundo Silva-Corvalán (1989) a Sociolinguística pode ser definida, em sentido amplo, como estudo dos fenômenos linguísticos que apresentam relação com os fatores sociais. Esses fatores sociais incluem os diferentes sistemas de organização política, econômica, social ou geográfica de uma comunidade, os fatores individuais que têm repercussão sobre a organização social em geral, como a idade, o sexo, o grau de escolaridade, a etnia do indivíduo e os aspectos históricos.

É, através da língua, que o ser humano expressa suas ideias, as ideias de sua geração, as ideias da comunidade a que pertencem as ideias de seu tempo. A todo instante, utiliza-a e contribui para a sua renovação e constante transformação. Cada falante é 


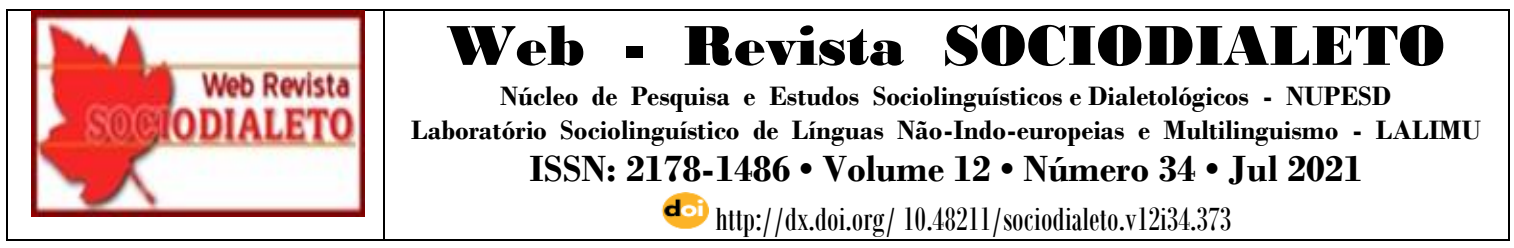

usuário e agente modificador de sua língua, nela imprimindo marcas geradas pelas novas gerações com que se depara.

Neste estudo, de caráter bibliográfico, seguimos a orientação da teoria da variação onde há a avaliação do quantum com que cada categoria postulada contribui para a realização de uma ou de outra variante das formas em competição. Na fala real, que constitui o dado do linguista, tais categorias se apresentam sempre conjugadas; isto é, na prática, a operação de uma regra variável é, sempre, o efeito da atuação simultânea de vários fatores.

Vale repetir que o pressuposto básico da variação no uso da língua é o de que a heterogeneidade linguística não é aleatória, mas regulada, governada por um conjunto de regras.

Do ponto de vista teórico, a pesquisa bibliográfica permitiu identificar e descrever as hipóteses e as estratégias através das quais o aprendiz constrói seu conhecimento linguístico, enquanto do ponto de vista pedagógico, esse estudo levou à compreensão da natureza do erro ortográfico, compreensão necessária à descoberta de formas sistemáticas para erradicá-lo. Lemle, grande contribuidora para o/a docente refletir sobre a relação entre alfabetização e linguística, lança questionamentos que representam um significativo avanço no estabelecimento de fundamentos linguísticos para o processo de alfabetização. Sendo assim, é necessário compreender as hipóteses e as etapas por que passam os alfabetizandos, analisando o desempenho real de aprendizes como processadores ativos na construção de uma teoria das relações entre o sistema fonológico e o sistema ortográfico.

A intencionalidade de apresentar resultado de pesquisa em comunidade rural baiana para evidenciar a ocorrência de fenômenos linguísticos como: semivocalização da consoante lateral palatal $/ \mathrm{K} /$; rotacismo nos grupos consonantais de consoante oclusiva ou fricativa + líquida lateral; monotongação de /ey/ e /ow/; síncope nas proparoxítonas e semivocalização do /1/ em posição final de sílaba, deu-se em virtude de alguns estudos da dialectologia e da sociolinguística no território brasileiro advertirem que em algumas comunidades rurais encontram-se tais fatos fônicos. 


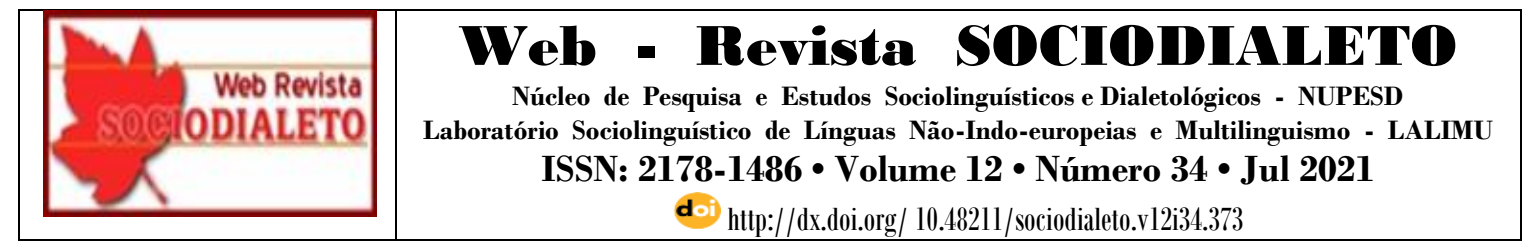

A realidade, portanto, é que toda língua varia mesmo; que toda língua é heterogênea; que o objeto que chamamos de língua não passa de um conjunto de variedades, de dialetos; que descrições apresentando a língua como homogênea são descrições úteis, mas são ficções. Mas o reconhecimento da heterogeneidade linguística não impede que se realize, em outro plano, uma descrição homogênea; ou que se procure estabelecer uma política de padronização, postulando uma norma, uma "língua padrão", uma "língua franca", de caráter especial, a funcionar dentro da mesma língua. Afinal, alguma uniformidade será útil para diversas circunstâncias: uso escrito, discursos oficiais, ensino estrangeiro, etc. As deformações começam quando o dialeto escolhido para ser a língua padrão passa a ser o "certo" (e os demais, portanto, "errados"); quando as normas que regem as variedades que não foram privilegiadas passam a ser "erros" e apenas se fala em a norma; única norma; quando o que é diferente passa a ser "errado".

De fato, o processo de legitimação de uma norma passa pela consolidação do poder. Sendo assim, uma variedade linguística é legitimada, quando é símbolo de uma tradição cultural, representante de um grupo de poder.

A alfabetização é uma atividade pedagógica, inserida no processo ensino/aprendizagem de línguas, que tem como alvo munir o sujeito aprendente com mais um instrumento de comunicação verbal, a escrita.

Seu objetivo primário concentra-se na recodificação de uma mensagem oral numa mensagem escrita e vice-versa. Seu objetivo último reside, no entanto, na utilização de substância gráfica como expressão de conteúdo, de uma maneira direta, sem utilizar a substância fônica como intermediária.

O/a professor/a que alfabetiza é um/a professor/a que ensina uma língua. Como se pode ensinar uma língua sem conhecer sua estrutura e seu funcionamento? A resposta a esta pergunta leva ao consenso de que o / a professor/a de língua, no exercício de sua função, deve não somente conhecer a língua que ensina, os métodos e as técnicas de ensino, bem como os aspectos psicológicos envolvidos neste processo, mas, também, precisa conhecer algo sobre a linguagem, objeto de seu ensino. 


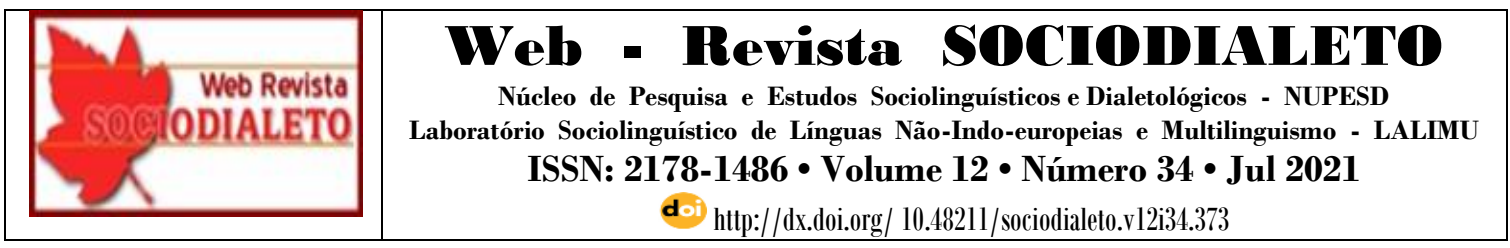

Essas colocações levam à certeza de que, embora a linguística não dê resposta a todos os "problemas" de alfabetização e suas respostas não sejam definitivas, o/a professor/a alfabetizador/a que tiver formação linguística poderá dela fazer um uso inteligente para aperfeiçoar o seu trabalho.

\section{Sociolinguística: explicações necessárias}

Com o surgimento da Sociolinguística, na década de 1960, a Linguística passa a fazer questionamentos que relacionam a mudança aos grupos sociais de cada comunidade linguística. Neste momento, fica estabelecida a relação entre a história social de uma comunidade de fala e os mecanismos linguísticos utilizados por seus falantes. As línguas só existem através de seus usuários (o povo) e a história desse povo determina a história dessa língua, na identidade dessa comunidade linguística.

Um dos estudos pioneiros envolvendo Alfabetização e Sociolinguística foi feito por Lemle e Naro (1977). O estudo investigava o uso variável da marca de concordância verbal de $3^{\mathrm{a}}$ pessoa do plural apoiado na teoria laboviana e tomou como base o cálculo das probabilidades que fornecem resultados mais seguros que apenas analisando-se os percentuais.

Lemle e Naro (1977) chegaram à conclusão que algumas formas verbais não fazem a concordância com seu sujeito com a mesma frequência que outras, a partir do estudo que fizeram para o Movimento Brasileiro de Alfabetização (MOBRAL) e a Fundação Ford. Levantaram dados da fala de analfabetos do Rio de Janeiro e constataram que, das variáveis estudadas, as que se mostraram mais favorecedoras de realização da concordância verbal foram as mais salientes, o que equivale afirmar que a diferença entre singular e plural interfere na aplicação da regra de concordância, assim como a distância entre sujeito e verbo: o sujeito mais próximo favorece a aplicação da regra e o mais distante inibe. Lemle e Naro (1977, p. 43-6)

A sociolinguística estuda a fala viva em situação real e observa fatos linguísticos com o objetivo de explicar a variação linguística. Considera a heterogeneidade linguística 


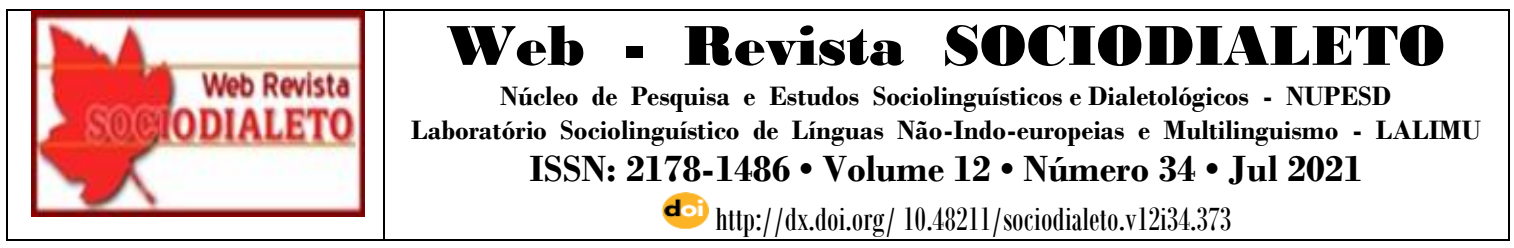

natural, ordenada e comum às línguas. Segundo Labov (2008), os falantes escolhem suas variantes pela identificação com seu grupo social, faixa etária e sexo/gênero. A variação é entendida como um fenômeno estruturado e regular, relacionado a aspectos linguísticos e sociais. Para efetuar um estudo sociolinguístico, deve-se levar em conta a comunidade de fala e não a língua. Entende-se por comunidade de fala um conjunto de falantes que compartilham um mesmo sistema de valores linguísticos, avaliando positivamente ou negativamente as variantes presentes nos padrões coletivos de comportamento linguístico dentro da comunidade. Para esse modelo teórico-metodológico, as pessoas de uma comunidade de fala não precisam falar exatamente igual, mas sim compartilhar traços linguísticos que distinguem seu grupo de outros.

Uma língua pode sofrer mudanças em qualquer parte, isto é, pode mudar em diversos aspectos: fonéticos, semânticos e pragmáticos, além de aspectos morfológicos e sintáticos. As mudanças também podem ocorrer no campo lexical. O nível de estudo mais abordado na análise das línguas é o fonético-fonológico. A sociolinguística teve, no seu surgimento, diversos trabalhos no campo da fonologia, mas, atualmente, já existem muitos trabalhos de abordagem, tanto morfológica, quanto sintática.

Discutem-se, também, os estudos de terceira onda na Sociolinguística que focalizam a atuação dos condicionamentos sociais sobre as formas linguísticas em variação. Os estudos de terceira onda na Sociolinguística têm como objetivo observar e analisar os condicionamentos sociais e as relações de poder no significado social da variação nas falas de pessoas que partilham da mesma comunidade de prática, mantendo os postulados dos estudos de primeira e segunda onda, mudando o foco (de comunidade de fala para comunidade de prática).

A Sociolinguística Variacionista revolucionou o estudo da mudança linguística através do conceito de mudança em progresso, contrariando teorias anteriores que defendiam que a mudança linguística não podia ser estudada durante o processo e, sim, após ter sido efetivada. Ao invés de analisar o resultado do processo através do qual uma forma é substituída por outra, a Sociolinguística analisa o processo de implementação da mudança como um processo de variação entre formas concorrentes, observado em uma 


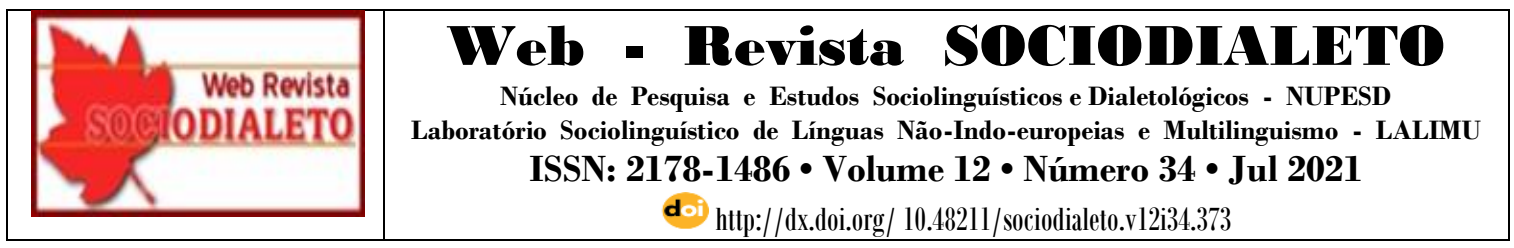

sincronia. Os estudos de Labov (2008) comprovaram que se pode identificar a mudança em progresso de uma língua, através da observação das faixas etárias, o que ele definiu como o estudo da mudança em tempo aparente. Essa perspectiva de entender a mudança veio superar a dicotomia saussuriana sincronia/diacronia, para a qual a mudança só poderia ser observada na história da língua, isto é, em sua diacronia.

No modelo variacionista, não é possível compreender o desenvolvimento de uma mudança linguística fora da estrutura social da comunidade na qual ela ocorre. Labov esclarece que a mudança é o processo de modificação por que passam as línguas e não o resultado deste processo. Ao se estudar o referido processo, analisa-se, de imediato, o caráter heterogêneo dos sistemas linguísticos. Essa heterogeneidade é regida por fatores internos e externos à língua que, desse modo, é analisada como um sistema heterogêneo, porém organizado, isto é, "a língua passa a ser concebida como uma estrutura inerentemente variável e a variação livre como passível de descrição sistemática, em função de restrições linguísticas e não linguísticas” (SCHERRE \& NARO, 1997, p. 94)

Outro fator importante e favorecedor da variação ou da mudança linguística é a escolarização do falante. Estudos atestam que, em caso de mudanças, os falantes mais escolarizados preferem as formas socialmente mais valorizadas, rejeitando as formas ditas populares. A escola tem, portanto, um papel muito forte na conservação da língua, pressionando os indivíduos a utilizarem a variante padrão. As classes sociais mais altas preferem as formas de maior prestígio social, as mais valorizadas socialmente, enquanto as classes sociais mais baixas utilizam as formas de menor prestígio, as formas estigmatizadas socialmente.

O estudo de uma língua nos permite observar sua história, a cultura e, sobretudo, a identidade de seu povo. A língua se mostra, no seu dia a dia, nas manifestações de seu povo, que a enriquece com toda a sua história, o que possibilita a variação e a mudança linguística.

Lucchesi (2006) aponta a realidade sociolinguística brasileira como polarizada, entre uma norma culta, definida a partir dos padrões de fala das classes média e alta e uma norma popular ou vernácula, reunindo os falares das classes baixas. A história da 


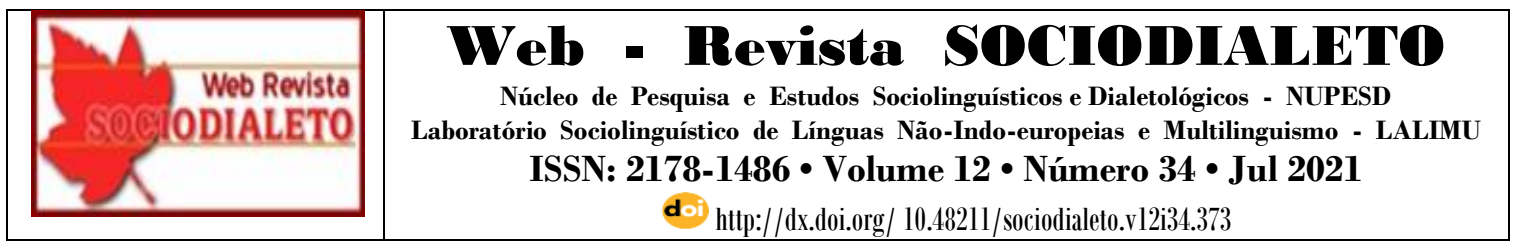

língua portuguesa no Brasil é vista através dessas duas vertentes. A partir do final do séc. XIX e no decorrer do séc. XX, violento e extenso processo de industrialização e urbanização provocaram profundas modificações no panorama socioeconômico do país. De um lado, o padrão europeu deixa de exercer tão proeminente influência sobre a normatização da língua. De outro lado, o nivelamento linguístico dos falares rurais e populares brasileiros modifica o panorama linguístico do Brasil, estabelecendo uma norma linguística para as camadas populares e outra para a elite do país.

Segundo Lucchesi (2006), a bipolaridade que marca a história sociolinguística do Brasil é destacada por Serafim da Silva Neto (1963). O português sofreu profundas alterações ao ser adquirido inicialmente pelos índios aculturados e, posteriormente, por escravos trazidos da África o que desencadeou um processo de transmissão linguística irregular que marcou decisivamente a formação das atuais variedades populares da língua portuguesa no Brasil.

Vitorino e Souza (2020), em entrevista à Cairu em Revista, refletem um pouco sobre: a contribuição que a Sociolinguística deu aos estudos linguísticos, como a Sociolinguística atua no estudo da língua, como ocorrem as mudanças linguísticas, como se dá a mudança em progresso, como se pode acompanhar a mudança de uma língua, o papel da escolaridade na variação linguística, a relação entre mudança e história da língua, as diferenças entre o português brasileiro e o português europeu, a contribuição das línguas africanas para a formação do português brasileiro e a polaridade linguística brasileira. As informações são oportunas para esclarecer e possibilitar o entendimento do leitor sobre a contribuição a Sociolinguística principalmente no contexto escolar, onde futuros educadores após uma leitura atenta podem encontrar interesse em aprofundar estudos indo em busca de outros materiais que os auxiliem no entendimento da relação da língua no contexto social.

\section{Sociolinguística e alfabetização: a compreensão da relação imbrincada}

O desafio da alfabetização é a transmissão/apropriação da norma padrão, sem pretender esconder ou suprimir as variedades linguísticas existentes devido à 


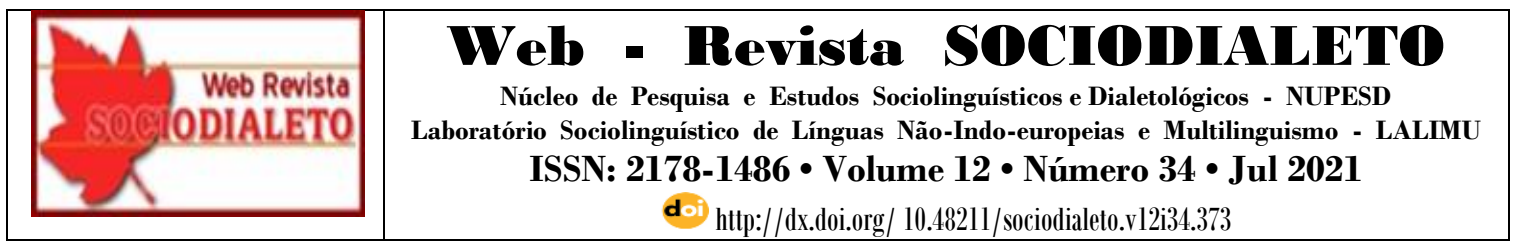

complexidade da nossa sociedade, o que significa uma atitude de respeito, de interesse e de incorporação ativa da cultura do aluno no processo ensino/aprendizagem.

Isso já é feito em outros países em outros países de línguas latinas, onde questões ligadas à ortografia e à gramática são trabalhadas com os alunos somente nos anos posteriores à alfabetização. Dessa forma, a apropriação da língua escrita durante a primeira etapa de seu aprendizado é vista como a construção de linguagem. É valorizada a capacidade do aluno de se expressar em seus padrões linguísticos através da língua escrita, para depois serem transmitidas as regras socialmente (FERREIRO, 1989).

O padrão registrado na gramática da língua escrita é fruto da "legitimação" de uma variedade linguística, associada à forma de falar dos grupos que estão no poder. Esse padrão é conhecido como variável "culta" da língua e identifica as pessoas que dele se utilizam como portadores de prestígio social.

O processo de ensino/aprendizagem da língua escrita é marcado tanto pela técnica intrínseca à língua, como pelos valores conceituais que sustentam a legitimação da norma padrão da língua. E ainda estão presentes neste processo as variações da fala em função das diferenças culturais, que se manifestam nas primeiras etapas do aprendizado da língua escrita.

Santos (2010), reportando-se à formação do educador alfabetizador e infância afrodescendente, enfatiza que:

[...] é preciso, na contemporaneidade, ir além dos aspectos cognitivos e psicológicos no processo de alfabetização das crianças sem, contudo, minimizar a sua importância. Assumir e perceber que as crianças e o próprio educador são sujeitos históricos e culturais é tarefa fundamental nos atuais delineamentos da alfabetização para a infância. [...]. (SANTOS, 2010, p. 95)

Para a pesquisadora Santos (2010), como sugestões de atividades que possam dar visibilidade e possibilitar a promoção da cultura afrodescendente nas classes de alfabetização, deve-se: a) ouvir e contar histórias, lendas e mitos africanos e afrodescendentes; b) cantar, escrever e ler músicas afrodescendentes. Essas sugestões 


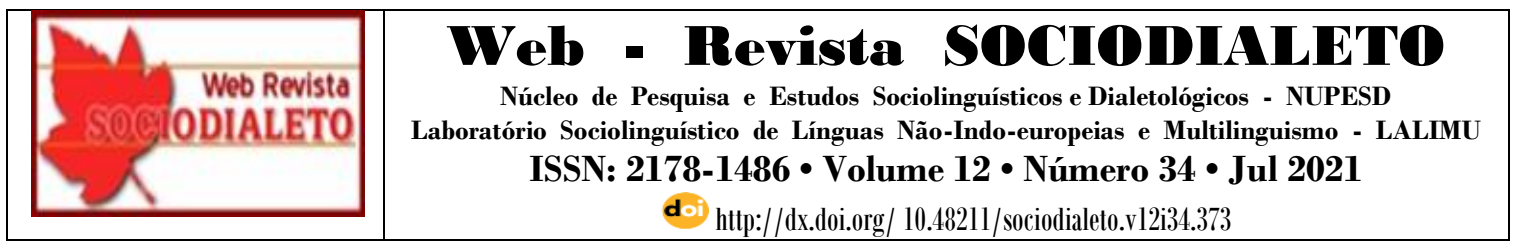

possivelmente possibilitarão aos educadores alfabetizadores conscientização de que a alfabetização começa na infância. Faz-se necessário, entretanto, "trazer a cultura das crianças de origem afrodescendente como conteúdo significativo no processo de alfabetização e defendê-las como sujeitos de direito [...]”. (SANTOS, 2010, p. 97).

No Brasil, esta questão ainda é mais acentuada no contexto rural pelo fato de, desde o início da alfabetização, ser cobrado um registro gráfico de acordo com as regras valorizadas socialmente. Soma-se à dificuldade inicial de se apropriar de uma ortografia correta, a desvalorização das formas de falar dos diversos grupos culturais de nosso país. Aí reside um fator de inibição no processo de aprendizagem da língua escrita que vai ser associado a outras questões, como a relevância do texto lido para as crianças e a função que a língua escrita tem em seu grupo cultural.

Vitorino (1999) lançou os seguintes questionamentos para realizar uma pesquisa sociolinguística: 1) Os indivíduos alfabetizados na zona rural têm consciência de que nem sempre os sons da fala são representados da mesma maneira na escrita; 2) Que peculiaridades características do dialeto falado por comunidades rurais trazem esses indivíduos; 3) Que “erros” de grafia cometem?; 4) Que explicação têm esses “erros”, à luz da sociolinguística?. O objetivo geral consistiu em investigar as estratégias que utilizam os alfabetizandos ao buscar transferir a forma sonora da fala à forma gráfica da escrita. A investigação foi de cunho sociolinguístico em uma comunidade rural baiana com inspiração nas reflexões de Labov (1963; 1964; 1966; 1967; 1972; 1987). Optou-se pela aplicação da técnica de ditado-mudo, com30(trinta) informantes de faixas etárias diferentes (F I - 7 a 14 anos; F II -15 a 25 anos; F III - 26 a 35 anos), naturais do povoado Caiçara, pertencente ao município de Paulo Afonso-Bahia. Fez-se exibição das gravuras para cada informante identificá-las oralmente e fazer, também, a codificação escrita do material exibido. A pesquisa teve a intenção de investigar os seguintes fenômenos linguísticos:

1. Semivocalização da consoante lateral palatal / $\Lambda$ / em vocábulos como: folha, orelha, milho e palhaço; 


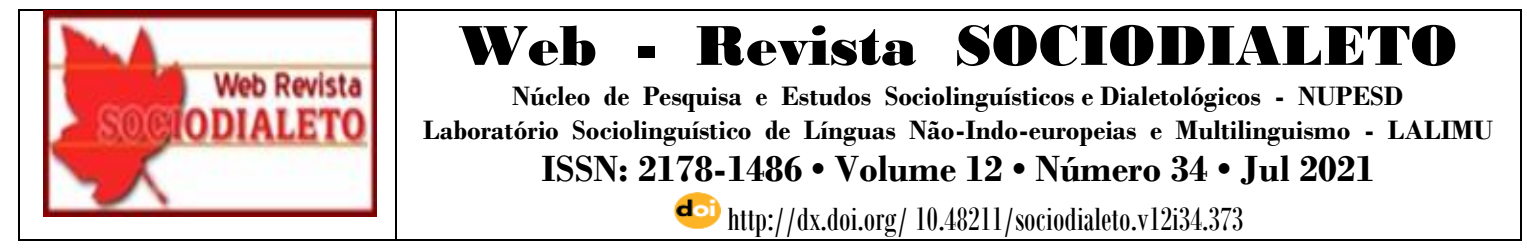

2. Rotacismo nos grupos consonantais de consoante oclusiva ou fricativa + líquida lateral, em vocábulos como: flor, blusa, planta e bicicleta;

3. Monotongação de /ey/ e /ow/, ou seja, passagem de um ditongo a um monotongo, verificação feita nos vocábulos: peixe, cadeira, vassoura e cenoura;

4. Síncope nas proparoxítonas que ocorre quando são emitidas como paroxítonas as palavras de acentuação proparoxítona, por perda de um ou mais de um segmento fônico, em palavras como: óculos, xícara, abóbora e lâmpada;

5. Semivocalização do /l/ em posição final de sílaba que ocorre quando há a emissão do /l / como [w], fato comum na maioria das áreas brasileiras, principalmente na fala. A verificação de ocorrência pode ser observada em palavras como: balde, calça, anel e sol.

Ao buscar explicação para a ocorrência dos "erros" encontrados nos fenômenos linguísticos selecionados, pôde-se concluir que esses "erros" podem ser agrupados em função de diferentes condicionamentos, isto é, esses "erros" resultam de três fatores: interferência da fala na escrita; idiossincrasias do código escrito; atuação de determinantes extralinguísticos (o sexo e a faixa etária dos informantes) que interferem na definição das condições sob as quais se realiza a mediação entre a fala e a escrita.

Em função dos processos de legitimação da norma padrão (que lhe acrescenta o adjetivo de "culta"), a linguagem, constituindo a consciência subjetiva dos alunos, comunica a posição social de quem a utiliza. Cria-se a falsa ideia de que somente os grupos sociais que utilizam a norma padrão da língua possuem cultura.

Sabendo que a escola não pode mudar os mecanismos de estratificação de nossa sociedade, para que a alfabetização não seja apenas um mapeamento das diferenças sociais é preciso considerar as peculiaridades psicológicas e socioculturais de cada alfabetizando. A partir da redefinição de poderes (de falar e ser ouvido) numa sala de aula, pode-se resgatar a noção de que todos possuem uma cultura que deve ser valorizada e respeitada, através de sua incorporação ativa no processo educacional. Isso somente acontecerá nos momentos em que o diálogo entre professor-aluno e aluno-professor for possível, favorecendo, assim, a produtividade na relação de ensino/aprendizagem. 


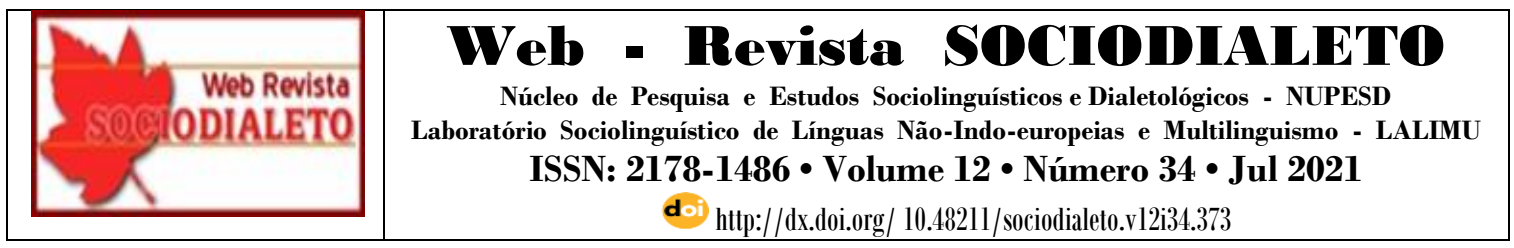

Numa classe de alfabetização, essas questões se tornam presentes na medida em que os alfabetizados são membros de grupos étnicos e de classes sociais muitas vezes diferentes daqueles a que pertence o alfabetizador.

Estudos demonstram que o tema alfabetização vem sendo analisado por diversos autores nas últimas décadas. Muitos trabalhos têm apontado para o fracasso da escola brasileira na alfabetização. Esse fenômeno é apresentado por Soares (1989), numa pesquisa sobre o estado de conhecimento na área de alfabetização no Brasil, como “contemporâneo do processo de conquista, pelas camadas populares, do direito à escolarização". Segundo a autora, a acelerada conquista do acesso à escola (para conquistar a competência no serviço de atendimento a especificidades dessas camadas que vêm conquistando seu direito à escolarização). Como as taxas mais altas de evasão e de repetência estão concentradas na fase inicial da escolarização, dedicada prioritariamente ao ensino da leitura e da escrita, Soares aponta, nesse trabalho, a alfabetização como o problema básico do tema educacional brasileiro.

Nessa pesquisa, Soares (1989) mostra que os estudos sobre alfabetização estão concentrados nas áreas de Psicologia, Pedagogia, Linguística, Psicolinguística, sendo que ainda existem trabalhos feitos a partir do referencial teórico das áreas de Estatística, de Literatura, de Audiologia, de Educação Artística e Interdisciplinar. Esses dados mostram a existência de multiplicidade de perspectiva e pluralidade de enfoques no estudo sobre alfabetização. Segundo a autora, só haverá uma contribuição efetiva para o problema do ensino/aprendizagem da língua escrita quando se tentar uma articulação das análises de diferentes áreas do conhecimento.

Como o problema do fracasso escolar ainda não foi resolvido, os dados apresentados por Soares já justificariam a necessidade de se continuar investigando a área da alfabetização, principalmente na zona rural.

Soares (2020) continua investindo em trabalhos com alfabetização. Atualmente tem uma parceria com a Universidade de Minas Gerais (UFMG) e a Secretaria de Educação do município de Lagoa Santa (MG), envolvendo as escolas da rede. Trata-se do Projeto ALFALETRAR (criado em 2007) cujo objetivo é "oferecer a todas as crianças 


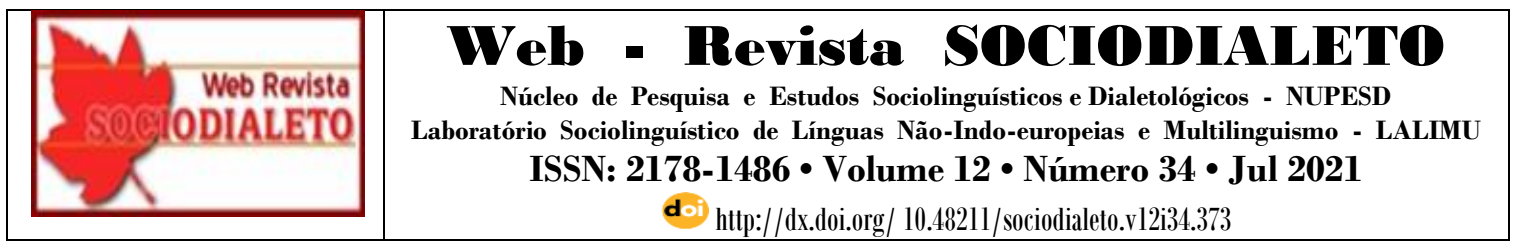

as condições necessárias para prosseguirem com sucesso em sua escolarização e, sobretudo, para se apropriarem de competências indispensáveis à plena inserção na vida social e profissional: competências de leitura e de produção textual”. (http://www.alfaletrar.org.br/sobre-o-alfaletrar. Acesso em 25. jan 2021)

Soares (2020), no livro Alfaletrar: toda criança pode aprender a ler e a escrever, em linhas gerais, esclarece ao leitor relações importantes sobre: alfabetização e letramento, a entrada da criança na cultura da escrita, o despertar da consciência fonológica, consciência fonêmica: a apropriação do princípio alfabético, leitura e escrita no processo de alfabetização e letramento e planejamento no processo de alfabetização e letramento. A respeitada pesquisadora sobre a temática alfabetização com a socialização dessa obra tão recente, fruto de experiência vivenciada no ciclo de alfabetização e letramento do município de Lagoa Santa-MG, expõe com detalhes como o Alfaletrar pode ser utilizado por todos/as aqueles/ as que estão envolvidos na alfabetização e no letramento principalmente das crianças em qualquer parte do território brasileiro. Longe de ser considerado como um receituário a ser seguido, a riqueza de detalhes da obra possibilita ao leitor/a reflexões sobre como toda criança pode aprender a ler e a escrever.

\subsection{Língua e fala}

A introdução do termo língua, fundamental para a linguística desde 1916, levanos à consideração da primeira das antinomias de Saussure: língua e fala (langue-parole a edição francesa). Essa dicotomia baseia-se na distinção que se estabelece entre o sistema (língua) e a realização do sistema (fala). A língua é o sistema de símbolos que formam a linguagem e que todos os falantes de uma comunidade linguística possuem, enquanto a fala é a realização, em cada ato, deste conjunto de símbolos. A língua apresenta, pois, uma natureza homogênea que permite superar metodologicamente a primeira dificuldade assinalada. A distinção entre língua e fala é a primeira verdade acerca da natureza da linguagem no pensamento teórico de Saussure. É evidente que a língua e a fala apresentam um caráter independente, pois nenhuma das duas poderia existir isoladamente; também parece claro que só é possível o estudo da língua se se toma como 


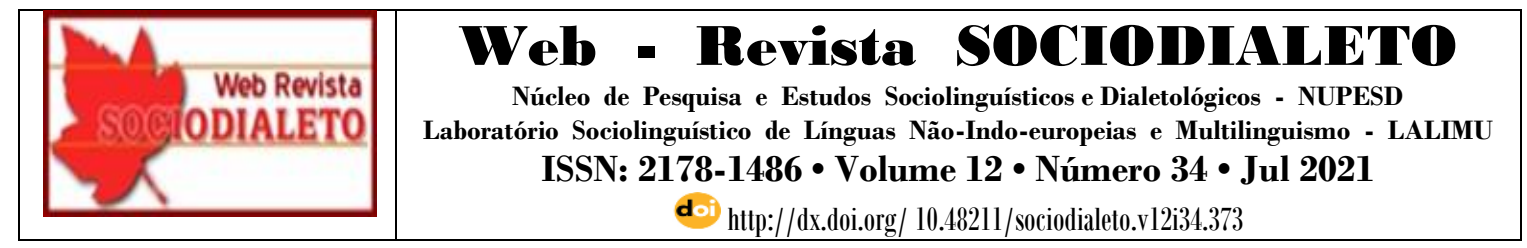

ponto de partida a observação e o estudo da fala, ainda que o interesse fundamental do investigador resida na descrição de cada sistema linguístico.

Eugenio Coseriu, por seu turno, critica a concepção saussuriana de língua como érgon (coisa feita, produto) e aceita o conceito de língua como enérgeia (dinamismo, criatividade, processo).

Coseriu (1973; 1978, trad. port.) afirma: “[...] a língua não é dinâmica porque muda, ou seja, porque a mudança é um fato, mas muda porque a sua natureza é dinâmica: porque a linguagem é atividade livre, isto é, criadora".

A mudança é uma característica essencial, necessária e universal das línguas. A língua muda porque não está feita, pronta, mas se faz continuamente pela atividade linguística e porque a língua só existe como técnica e modalidade de falar: é atividade criadora, finalista. O falante cria ou estrutura sua expressão, utilizando uma técnica e um material anterior proporcionado por seu saber linguístico. A pergunta seria: por que o falante não inventa totalmente sua expressão? O falante utiliza modelos anteriores porque é um ser histórico. O fundamento da historicidade do homem é a linguagem. Pela linguagem se manifesta a intersubjetividade, o ser com o outro, que coincide com o ser histórico do homem.

Seguindo o pensamento de Coseriu, vê-se que a língua não se impõe ao falante, mas se lhe oferece. $\mathrm{O}$ falante dispõe dela para realizar sua liberdade expressiva. Mudança e variação são meros acidentes e pertencem à essência da língua: é a manifestação da criatividade da linguagem a história de todas as línguas.

Coseriu (1973, 1978, trad. port) ratifica: "Por conseguinte, se a língua é a todo instante sistema e se a todo instante 'a encontramos mudada', isto significa que muda como sistema [...]". Para Coseriu, buscar uma causalidade na evolução dos fatos linguísticos, em sua distribuição, é um resíduo neogramático, pertencente à época da língua como 'organismo vivo', natural. A linguagem humana pertence ao domínio de liberdade e da finalidade, e, como tal, os fatos linguísticos não podem interpretar-se e explicar-se em termos casuais. 


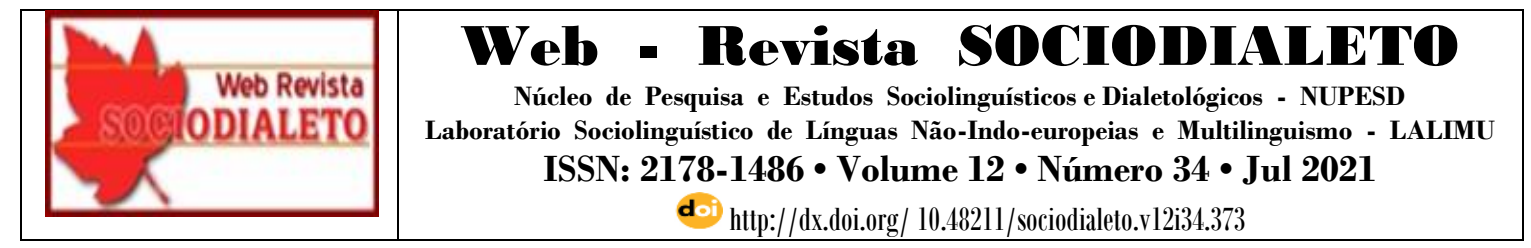

\subsection{Reflexões sobre a língua falada e a língua escrita}

Não se pretende esgotar a bibliografia referente ao assunto, apenas focalizaremos os estudos que nos parecem mais significativos, que corroboram e justificam nossa análise.

Para a pesquisadora em linguística Desbordes (1983), a língua oral goza de certa prioridade, independência e superioridade em relação à escrita. É que, na evolução da humanidade, a língua escrita teve a finalidade de representar culturalmente a oralidade; de, por assim dizer, fotografar esta última. Por isso, para esta autora, não é errôneo dizer que, de certa forma, a escrita tem, subjacente ao seu papel fundamental de comunicação e expansão cultural, a finalidade de representar a língua falada, pois representa o que existe de comum a todas as vozes falando uma mesma língua.

É ainda em Desbordes que encontramos uma justificativa convincente para estabelecer a distinção entre oralidade e escrita. Para ela, a escrita tem uma certa tendência autonomista que, na maioria das vezes, é bastante limitada.

Diniz (1987) afirma que acontecem diferenças entre escrita e fala e todos os níveis, a saber: nos níveis grafo-fonológico, sintático-semântico, lexical e sintático. No primeiro nível, a diferença se dá na produção-percepção. Na fala, as mensagens vocais se desenrolam numa cadeia linear/temporal, enquanto na escrita, por sinais gráficos, numa cadeia linear/espacial. Outro aspecto assinalado é o encadeamento dos sons da fala que não apresentam uma fronteira nítida na passagem de um som ao outro e, muitas vezes, as propriedades de um som projetam-se nos sons vizinhos. Observa-se, por exemplo, a pronúncia do plural de casa nas duas frases: as casas amarelas e as casas pequenas (CAGLIARI, 1989, p. 49). É constatável também:

Os usuários da língua, não raramente, sentem-se constrangidos na hora de escrever, não por causa do conteúdo, mas da grafia de certas palavras. Na verdade, os conteúdos podem ser discutidos ou mesmo questionados, mas a grafia das palavras revela de imediato o grau de escolaridade das pessoas. Certos erros podem até passar despercebidos por muitos, como escrever toráxico em vez de torácico, porém, outros 


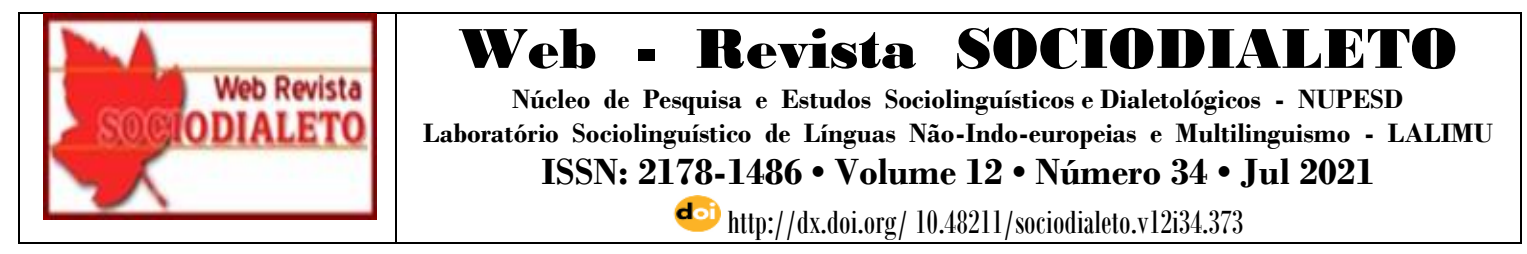

são inadmissíveis, como escrever peçoa, dice, familha etc. Nas conversas sobre linguagem, entre o povo comum, não é raro encontrar alguém que diz que não sabe escrever, querendo com isso dizer que não domina a ortografia das palavras. Em geral, ninguém duvida que os falantes nativos não saibam falar e, quando se julgam maus usuários da língua, no mais das vezes, isso tem a ver com o fato de usarem uma pronúncia dialetal estigmatizada que costumam, em alguns casos, transferir também para a escrita. É o caso da pessoa que fala mar em vez de mau, achemo em vez de achamos, comprá em vez de comprar e que, pela pouca instrução que tem, costuma trazer para a escrita as questões de variação [...] (CAGLIARI, 2002, p. 2)

No nível sintático-semântico da fala, pelo contexto situacional, observa-se uma ruptura da construção gramatical, repetição de palavras, frases inacabadas e outros aspectos que são substituídos por gestos, subentendidos, grau de intimidade entre os interlocutores, domínio do assunto abordado, etc. $\mathrm{Na}$ escrita, a ausência do contexto situacional exige uma estrutura gramatical mais rígida, como por exemplo, o uso abundante de sinônimos para evitar repetições, concordância predominantemente gramatical, etc.

No nível lexical, a fala apresenta um vocabulário mais reduzido, menos formal e de domínio do grupo. Na escrita o vocabulário tende a ser mais amplo, mais formal e, nem sempre, de domínio do grupo; por isso, muitas vezes, uma leitura nos remete ao dicionário.

No nível sintático, o modo de codificar a mensagem na fala e na escrita é estrategicamente diferente. Alguns dos fatores que determinam essa diferença são a necessidade de manter a atenção do interlocutor na fala, e a de não sobrecarregar a sua memória com excesso de informação nova, como também a impossibilidade de se voltar atrás e apagar ao que foi dito; sem falar do contexto, que resolve ambiguidades e complementa o ato linguístico. Na escrita, podem-se usar frases longas, elementos intercalados e, quando há uma mudança de plano, pode-se apagar ou reescrever o texto. Por outro lado, não se conta com o contexto situacional nem com as reações e interferências do ouvinte. Diniz afirma, ainda, que o falante, conhecendo instintivamente 


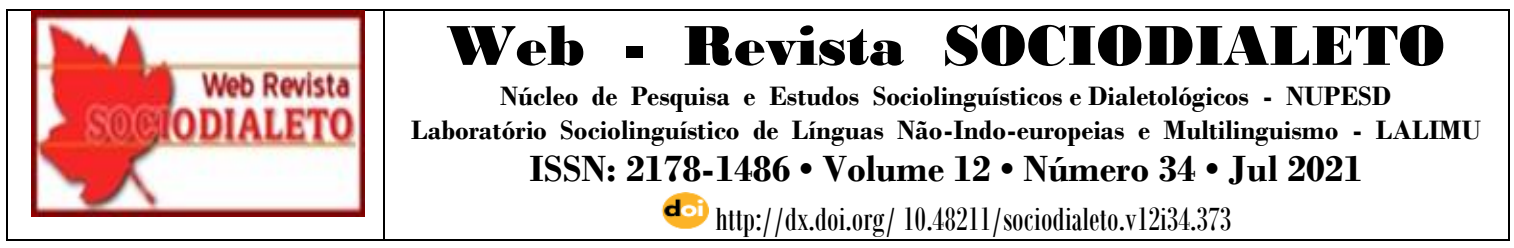

dificuldades de processamento para a compreensão da fala, que são maiores que a da escrita, procura recursos que resultam numa facilitação desses processamentos.

A proposta de isomorfia parcial entre a fala e a escrita traz implicações pedagógicas evidentes para a alfabetização. E, como afirma a própria autora, seja a escrita entendida como um código distinto e autônomo da fala, seja ela entendida como retrato da fala-padrão, em ambos os casos a fala do aluno será desconsiderada e, acreditamos, estigmatizada pela escola no processo de ensino/aprendizagem da leitura e da escrita.

Percebemos que o ensino da língua materna na escola reduziu-se quase que exclusivamente a um treinamento da manifestação da escrita. Dessa sobreposição da escrita sobre a fala, Saussure, nos diz:

[...] o objeto linguístico não se define pela combinação da palavra escrita e da palavra falada; esta última, por si só, constitui tal objeto. Mas a palavra escrita mistura-se tão intimamente com a palavra falada, da qual é a imagem, que acaba por usurpar-lhe o papel principal; terminamos por dar maior importância à representação do signo do que ao próprio signo. É como se acreditássemos que, para conhecer uma pessoa, melhor fosse contemplar-lhe a fotografia do que o rosto. (1969, p. 34)

Os profissionais da escola, e, sobretudo, aqueles envolvidos com a aprendizagem da língua, precisam romper com a postura ideológica e discriminatória em relação às variedades dialetais, aprofundando seu conhecimento teórico de modo a perceber que

[...] a valorização de formas linguísticas é uma construção social, ditada pela organização dos grupos humanos e que, portanto, não existe a boa ou a má linguagem em si mesma [...] uma variedade linguística vale o que valem na sociedade os seus falantes. Vale como reflexo do poder e da autoridade que eles têm nas relações sociais e econômicas. (GNERRE apud GERALDI, 1984, p. 41)

Não queremos, com isso, defender as formas dialetais consideradas não cultas como objeto do processo de ensino porque temos consciência de que a linguagem constitui "o arame farpado mais poderoso para bloquear o acesso ao poder" (GNERRE, 


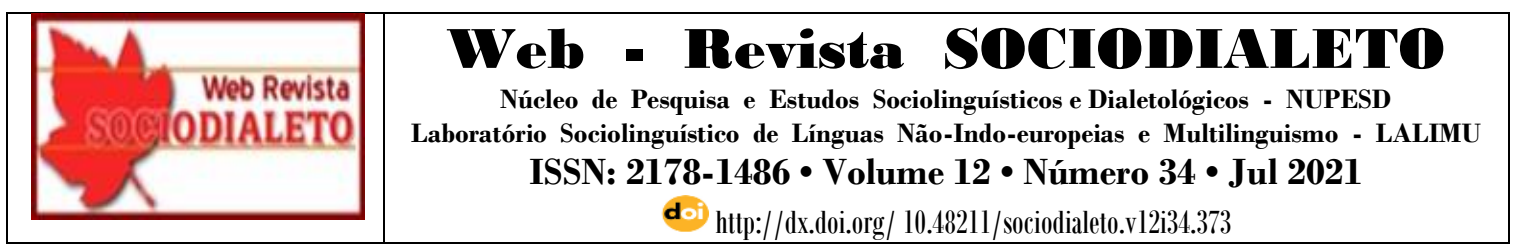

1985, p. 45). Somamos com Geraldi (1984), Soares (1989), entre outros, que afirmam a necessidade de as classes populares aprenderem a usar a norma padrão para que a transformem num instrumento fundamental e indispensável para a aquisição do conhecimento formal e para a construção de uma nova ordem social e política que seja de fato democrática para todos os segmentos sociais. Esse acesso não deve ocorrer às custas da destruição da linguagem de origem do aprendiz, ao contrário, deve tomá-la como ponto de partida.

\subsection{Diferença entre o sistema fonológico e o sistema ortográfico}

A necessidade de compreender o objeto do conhecimento na alfabetização remetenos também, e, sobretudo, às diferenças entre o sistema fonológico e o sistema ortográfico.

[...] É impressionante como os erros dos alunos revelam uma reflexão sobre os usos linguísticos da escrita e da fala. Só a escola não reconhece isso, julgando que o aluno é distraído, incapaz de discriminar, aprender, memorizar, se concentrar no que faz. Ele se concentra e reflete mais do que se possa pensar. E quando é injustamente criticado pelo seu esforço, desilude-se coma escola, ou tenta aprender apesar dela. (CAGLIARI, 1989, p. 61)

Muitos dos erros dos alfabetizandos têm sua origem no uso da oralidade como única matéria-prima da escrita, uma vez que não podem lançar mão da sua memória de leitor, como o faz o adulto, ou recorrer ao uso do dicionário. Essa questão, tão relevante, das diferenças entre o fonológico e o ortográfico no nosso sistema de escrita é praticamente ignorada pelos alfabetizadores. É dessa diferença que tratamos a seguir.

Silva (1981) adverte-nos que para fazer a transferência da forma sonora para a forma gráfica, temos e/ou devemos abordar três aspectos distintos do sistema fonológico e determinar sua correspondência na escrita: a) o aspecto físico da corrente da fala (o som propriamente dito); b) o som como elemento significativo, no sistema de comunicação (as entidades segmentáveis); c) traços que incidem sobre a corrente da ala codificando a mensagem (as entidades suprasegmentais). 


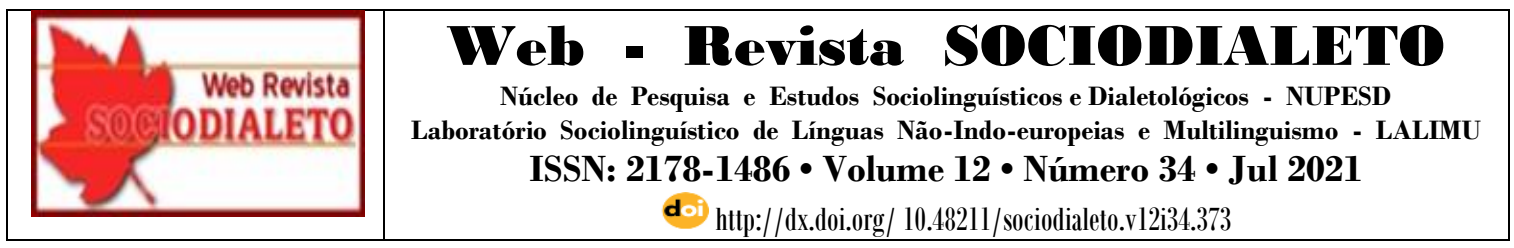

A forma física do som se relaciona com a letra, forma física da escrita. Esse relacionamento pode levar a uma atitude pedagógica que consiste em utilizar o ensino de letras isoladas. Com muita razão, técnicos em educação têm repudiado este método. Embora o elemento fonológico em questão deva ser transferido para a escrita, não será esta a maneira recomendável de realizar a transferência, desde que o fone isolado, como a letra na mesma condição, não tem significado para o aluno.

Fries (apud SILVA, 1981) propõe, não obstante, que o docente, mediador do conhecimento, não deve abandonar totalmente o ensino das letras. Ele aconselha iniciarse a alfabetização com um treinamento que leve o aluno a distinguir as formas gráficas entre si, porém sem relacioná-las com seu valor fonológico.

Sobre a arbitrariedade na representação escrita, Abaurre (1987, p. 129-135) nos lembra:

Como um sistema de representação fonética, um som representado por uma só letra e uma letra representada por um som, temos nas relações biunívocas ideais, o $\mathbf{p}$, o $\mathbf{b}$, o f e o $\mathbf{v}$ que funcionam como símbolo de um alfabeto fonético para, talvez, todas as variedades do português do Brasil. Maior parte das letras representa um dado som num dado contexto. Há partes arbitrárias no sistema que são os casos de letras que no mesmo contexto podem representar o mesmo som, por exemplo, o $\mathbf{s}$, e o $\mathbf{z}$ intervocálicos.

As relações entre o sistema fonológico e o sistema ortográfico têm sido objeto de análise de diversos pesquisadores que procuram observar sua influência na aprendizagem de escrita e/ou da leitura. Lemle (1987), partindo de uma discussão das relações entre os dois sistemas e abstraindo fatores intervenientes, aponta hipóteses que o alfabetizando constrói acerca das relações entre os sons da fala e as letras do alfabeto, propondo, com base nessas hipóteses, três etapas a serem respeitadas no processo de ensino/aprendizagem da língua escrita.

Conforme a autora, o processo que envolve essas etapas caminha do mais motivado ao menos motivado foneticamente, representando as relações entre o sistema 


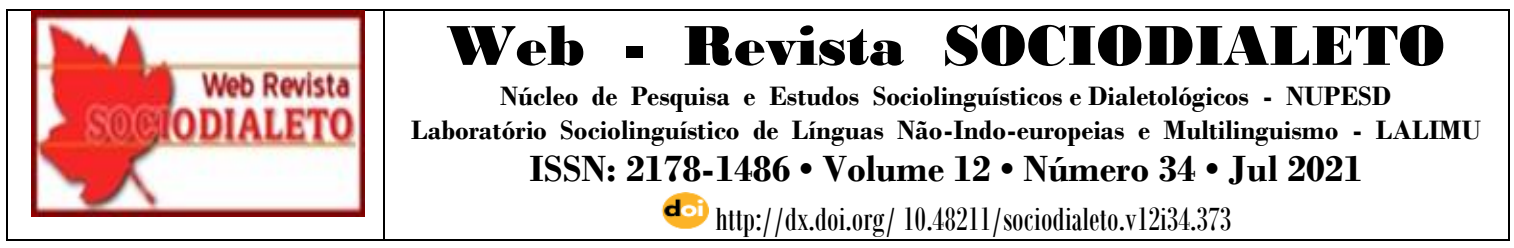

ortográfico e o sistema fonológico, identificadas na fonologia da língua portuguesa, mais especialmente no dialeto carioca.

Antes que a criança vença as etapas sugeridas "há alguns saberes que ela precisa atingir e algumas percepções que ela deve realizar conscientemente" (LEMLE, 1987, p.7). São essas habilidades básicas apontadas: a capacidade de compreender o que seja uma relação simbólica; a necessidade de discriminar as formas das letras; a conscientização da necessidade de discriminar os sons; a captação do conceito da palavra para compreender as fronteiras vocabulares e separá-las corretamente; a compreensão espacial da página em nosso sistema de escrita. Tendo dominado essas habilidades, acredita Lemle que temos "um freguês pronto, desejoso de aprender a ler e a escrever" (idem, p. 15).

A primeira etapa refere-se à teoria do casamento monogâmico entre sons e letras, quando o aprendiz alimenta a crença "ideal e perfeita de que cada letra tem seu som e cada som tem sua letra". Lemle sugere que o alfabetizador explore ao máximo essa fase, trabalhando com as consoantes $\mathbf{p}, \mathbf{b}, \mathbf{t}, \mathbf{d}, \mathbf{f}, \mathbf{v}$ e com a vogal a por representarem, em qualquer posição, sempre a mesma unidade fonêmica. Num segundo momento dessa etapa, deve-se introduzir as letras que representam diferentes sons, segundo sua posição na palavra. Sobre o tempo de trabalho baseado nessa hipótese monogâmica, afirma que "É impossível ater-se a ela por muito tempo, sob pena de permitir que o aprendiz se fixe com excessivo apego a um conceito ilusório da rede de relações entre sons e letras. (LEMLE, 1987, p. 27)."

A segunda etapa, a da teoria da poligamia com restrições de posição, decorre da rejeição da hipótese monogâmica entre sons e letras. O contato com o material escrito e com as informações do professor farão o aluno perceber que em determinadas palavras o som da letra I não é [l] e sim [w], que em algumas posições o som da letra o é [u] e o som da letra é [i].

Com o propósito de ajudar o alfabetizando a perceber as restrições da hipótese monogâmica, Lemle propõe uma série de atividades para que ele construa uma nova hipótese sobre essa relação som/grafia. O aluno deve levantar dados sobre os sons das 


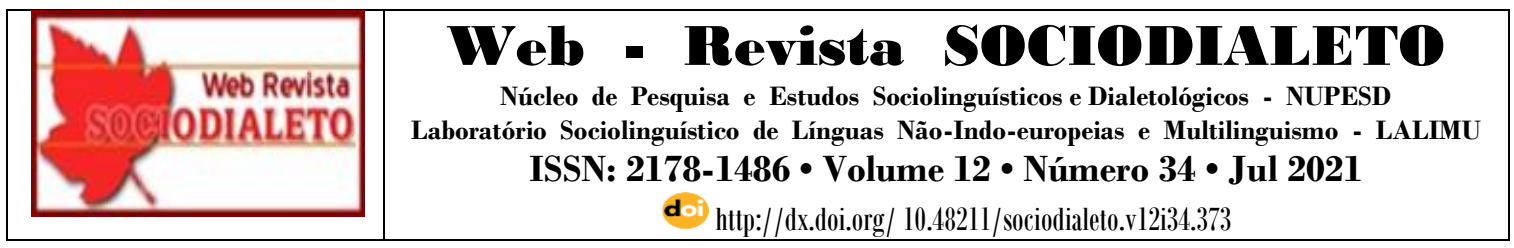

letras em diferentes situações e montar listas ou cartazes agrupando essas diferenças. Esse trabalho propicia "a passagem da primeira hipótese (de monogamia) para a segunda hipótese (de poligamia condicionada pela posição)" e representa "um passo de importância crucial na construção do conhecimento do alfabetizando a respeito do nosso sistema de escrita" (LEMLE, 1987, p. 29).

Quando o professor aferra-se à crença de que há um modo correto de fala e toma como modelo a escrita, artificializando um jeito de falar que só existe dentro das salas de aula de alfabetização, a tendência é os alunos se manterem na primeira hipótese, da relação monogâmica entre sons/letras. Nas palavras da autora:

Essa maneira especial de pronunciar as palavras pode ser interpretada como um artifício didático usado pelos professores para preservar a validade da teoria monogâmica do sistema de escrita. Mas isso é um erro. Tentar protelar a teoria monogâmica é tremendamente contraproducente, só servindo para ancorar o aluno numa etapa pela qual ele inevitavelmente passa, mas da qual deve ser prontamente ajudado a sair. (LEMLE, 1987, p. 30)

A passagem da primeira para a segunda etapa se completa quando o aluno compreende os critérios de representação sonora das letras em função de sua posição na palavra. O que não significa que deixará de cometer erros ortográficos, pois persiste a tarefa ainda mais penosa de reconhecer as "relações arbitrárias entre letras e sons" (LEMLE, 1987, p. 31)

A terceira etapa é a da consciência das partes arbitrárias do sistema ortográfico, pois nele encontramos um grupo de letras que, numa mesma posição, pode representar o mesmo som, e a escolha entre uma e outra é totalmente arbitrária do ponto de vista fonológico. O fonema /z/ intervocálico, por exemplo, pode ser representado por $\mathbf{s}, \mathbf{z}$ ou $\mathbf{x}$, como em casa, exame, cozinha.

Tomemos outro exemplo, em que a hipótese de restrição pela posição, como no caso anterior, não mais serve de orientação ou regra para escrita ortográfica. E o caso do som [s], que pode ser representado por ss, ç, sç, SC (russo, moça, cresça, cebola, asceta). Sem abrir mão da segunda hipótese, o alfabetizando deve mantê-la e organizar suas ideias 


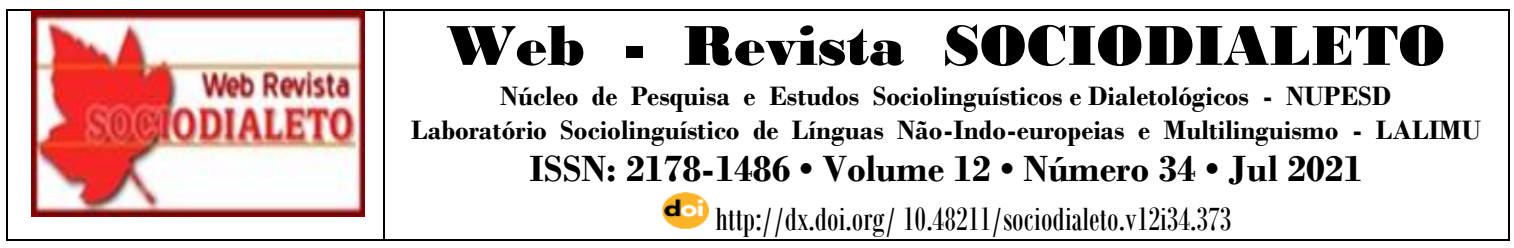

de maneira a atender essa nova exigência e "deverá resignar-se a memorizar a escolha da letra certa, individualmente para cada palavra". Vencida essa terceira etapa, o alfabetizando terá construído uma teoria sobre a correspondência entre letras e sons na nossa língua escrita, assim definida: Para cada som numa dada posição, há uma dada letra; a cada letra numa dada posição, corresponde um dado som. Em certos ambientes, certos sons podem ser representados por mais de uma letra. (LEMLE, 1987, p. 32)

Para que o alfabetizando organize e estruture seu conhecimento a respeito dos fatos que se enquadram na terceira hipótese, a autora propõe que o alfabetizador responda corretamente a todas as perguntas, dando-lhe informações históricas sobre as mudanças ocorridas em nossa língua que, originada do latim, antigamente era bem diferente da que falamos hoje.

É preciso mostrar, esclarece a autora, que a língua escrita conserva a memória do passado, ou seja, retém a lembrança de pronúncias que antigamente eram diferentes; é a tradição do passado, presente na escrita. Neste caso, não podemos recorrer ao som da fala nem condicionar o uso da letra à sua posição na palavra, o que temos a fazer é memorizar essas escritas. O que será feito por toda a nossa vida de usuários e produtores dessas modalidades de língua e, quando a dúvida surgir, recorremos ao dicionário ou à memória dos amigos com quem interagimos.

Com a intenção de auxiliar o alfabetizador na tarefa de identificar, compreender e avaliar os erros dos alfabetizandos, e assim diagnosticar com precisão a etapa em que se encontra o aluno, Lemle (1987) aponta os erros mais frequentes em cada uma das etapas discutidas.

Acredita-se que, de posse desses dados, o professor pode propor atividades, fundamentadas do ponto de vista linguístico, que façam o aluno avançar em suas hipóteses sobre a escrita.

Consideramos a proposta de Lemle um instrumento valioso na orientação de prática pedagógica que possibilite ao aluno a compreensão do sistema ortográfico da escrita, porém entendemos que a sua proposta de gradação na apresentação das relações entre sistema fonológico e sistema ortográfico deve se constituir num trabalho sistemático 


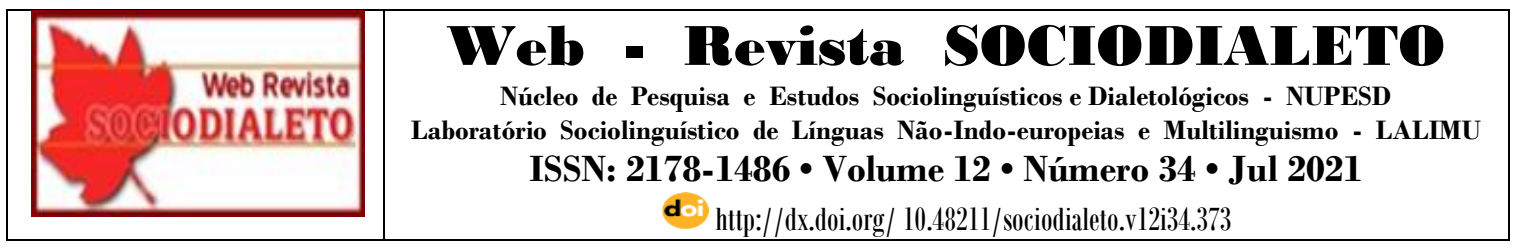

de "organização" a ser introduzido após a aquisição da base alfabética da escrita. Isso porque, segundo Ferreiro (1992), esta ideia de complexidade corresponde a uma lógica do adulto alfabetizado. Para a criança que inicia o seu processo de alfabetização, é fundamental o contato irrestrito com a escrita para que alcance êxito em suas conceitualizações. A própria Lemle corrobora esse ponto de vista, ao afirmar:

É claro que não podemos nos agarrar com rapidez ao intuito de manter o alfabetizando resguardado por algum tempo das complicações da escrita. As palavras vão jorrar de todos os lados, as crianças vão trazê-las, e não seria sensato exagerar o peneiramento dos dados. Se as letras indesejadas forçarem sua entrada, será preciso adiantar a explicação de que essas letras podem, às vezes, ter outros sons, quando colocadas em outras posições. (LEMLE, 1987, p. 27)

\subsubsection{Escrita ideográfica \& escrita fonográfica}

Desde Saussure, a ciência linguística estabeleceu que a linguagem humana se realiza através de signos linguísticos. Cada um desses signos é a união de "sons" e "ideias". Os sons constituem o que chamamos de significante do signo linguístico; as ideias constituem o significado que o signo veicula. Por exemplo, quando dizemos a palavra "CASA", unimos os sons $[\mathrm{k}]+[\mathrm{a}]+[\mathrm{z}]+[\mathrm{a}]$ a um significado - por exemplo, "moradia" - e, então, com esta palavra, fazemos referência a algo que existe no mundo. Neste sentido, podemos dizer que o signo linguístico é a linguagem que representa o mundo, que faz referência a ele. Mas é verdade que a linguagem não é igual ao mundo, não é a sua reprodução (não é a sua cópia).

Um exemplo disto é como a relação do signo com o mundo é arbitrária: na nossa cultura, o signo "CASA" só se refere ao objeto "casa" por uma convenção arbitrária social. Nada impedirá que, através de outra convenção arbitrária social, tivéssemos chamado "CASA" de "house", "haus" ou "maison" - como acontece em outras línguas. Entretanto, depois que ficou estabelecido que "casa" deve se chamar "CASA", a relação entre o significante $/ \mathrm{kaza} /$ e o significado "casa" não pode ser mais mudada - caso contrário 


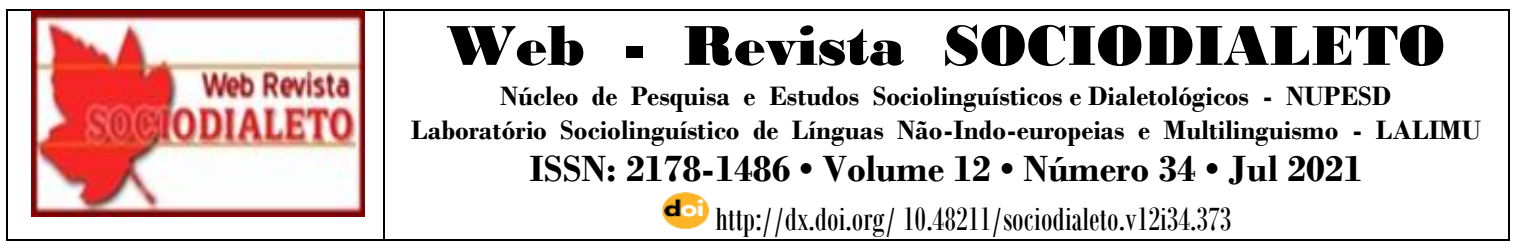

acontecerá uma mudança histórica na língua e surgirá, então, uma nova palavra ou um novo uso da mesma palavra.

Desde cedo, a humanidade sentiu necessidade de registrar, guardar a sua linguagem. Foi desta necessidade que surgiu a escrita. Por causa da própria natureza do signo linguístico, o homem percebeu desde cedo que havia dois caminhos a seguir (embora, historicamente, um tenha precedido o outro):

1. Representar o significado (a ideia) veiculado pela palavra e, a partir do reconhecimento deste significado, chegar aos sons que formam esta palavra, na leitura.

2. Representar os sons de uma palavra e, a partir do reconhecimento desses sons, na leitura, chegar ao significado desta palavra, às ideias a ela associadas.

A primeira maneira de registrar a linguagem, escrevendo a partir dos significados, das ideias, dá-se o nome de escrita ideográfica; a segunda, que escreve a partir dos sons das palavras, é chamada de escrita fonográfica. Todas as línguas do mundo podem ser escritas a partir de qualquer desses dois tipos de escrita, porque todas elas são compostas de sons unidos a significados, embora cada língua faça a sua escolha específica quanto ao sistema que utiliza para escrever. Portanto, para exemplificar os tipos de sistema de escrita, podemos usar a nossa própria língua, já que ela também é composta de signos. Começaremos com a escrita ideográfica.

\subsubsection{Escrita Ideográfica}

Como já foi mencionado anteriormente, a escrita ideográfica é todo sistema que parte da representação das ideias veiculadas pelas palavras, para depois chegar aos seus sons. Ao contrário do que muita gente pensa, este sistema não é mais primitivo do que o fonográfico, porque foi o primeiro a surgir, historicamente. Existem línguas, como o chinês, por exemplo, que até hoje utilizam este sistema como forma de escrita.

\subsubsection{Escrita Fonográfica}




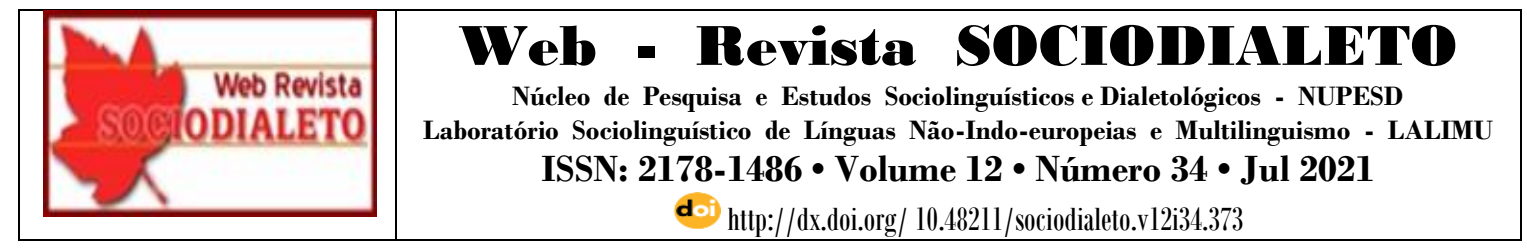

A escrita fonográfica é aquela que representa a linguagem partindo da representação dos seus sons. Neste tipo de sistema de escrita, os significados veiculados pelas palavras são recuperados, na leitura, através do reconhecimento, primeiro, dos sons da palavra representada; depois de identificada a palavra, é automática a recuperação da ideia que o escriba quis passar, uma vez que (como já foi visto) todo signo linguístico tem dentro de si, ligados indissoluvelmente, um significante (sons) e um significado (ideias).

Existem muitas maneiras de se representar os sons de uma palavra. Podemos representar as suas sílabas, os seus segmentos e até partes maiores - ou mesmo a palavra como um todo. A seguir, explicaremos brevemente cada um desses tipos de escrita fonográfica, partindo de exemplos de escritas hipotéticas do português.

\subsubsection{Escrita Silábica}

Vamos supor que quiséssemos representar o português, na escrita, atravésda representação das suas sílabas. Para fazer isto, precisaríamos propor um símbolo para cada sílaba existente na nossa língua. Desta maneira, haveria um símbolo para BA, outro para BE, outro para BRA, um outro ainda para BAR, e assim por diante. Se assim fosse, precisaríamos de um silabário (uma lista de todas as sílabas do português com seus símbolos correspondentes na escrita).

\subsubsection{Escrita Consonantal}

A escrita consonantal é um tipo de escrita que foi criada para representar, principalmente, algumas línguas semíticas, que possuem uma característica muito especial que permite o uso desse sistema; elas possuem apenas três vogais - a, i e u. Com este repertório bastante restrito de vogais, não há necessidade de escrevê-las, pois elas podem ser facilmente descobertas pelo contexto.

Como o seu próprio nome já diz, o sistema de escrita consonantal consiste em representar as palavras através da escrita de seus sons consonantais. Escolhemos, como pode ser visto abaixo, alguns símbolos para representar algumas das consoantes do 


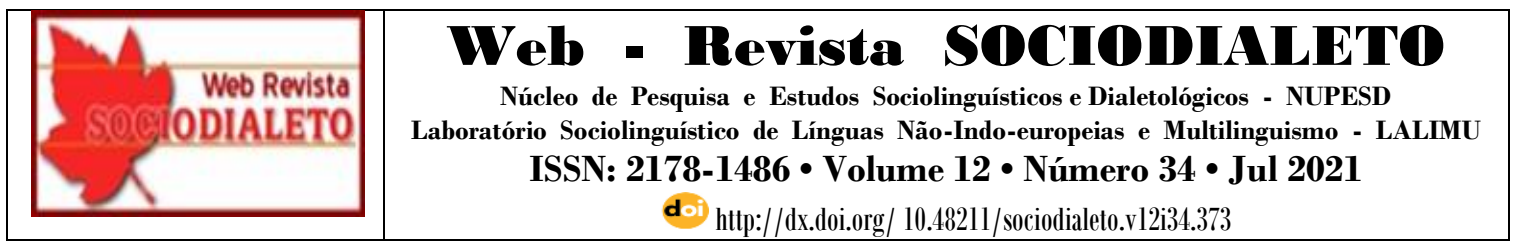

português, para podermos exemplificar o mecanismo deste tipo de escrita. Como pode ser observado no exemplo abaixo, este não é um sistema muito funcional para representar uma língua como o português, que possui muitas vogais, (sete vogais orais - $\underline{\mathrm{a}, \mathrm{e}, \mathrm{e}, \mathrm{i}, \mathrm{o}}$ $\underline{o}$ e $\underline{\text { u}}$, porque geraria muitas dúvidas a respeito de qual palavra estaria realmente representada. Além disso, ficaria a dificuldade de como escrever monossílabos compostos unicamente de vogais, como existe em nossa língua.

Embora existam várias línguas que usam um sistema consonantal de escrita, não existe um sistema vocálico de escrita, já que seria quase impossível reconhecer qual teria sido a palavra registrada. Isto porque todas as línguas possuem um número muito menor de vogais do que de consoantes no seu sistema fonológico.

\subsubsection{Escrita Fonética (ou alfabética)}

A escrita fonética consiste em representar os sons da fala, exatamente conforme eles foram pronunciados. Muitas vezes, quando as pessoas se referem a um sistema fonográfico, estão na realidade referindo-se a um dos tipos de sistema fonográfico, a escrita fonética. Outras vezes, confundem-se, também, as noções de escrita fonética e escrita ortográfica (que será apresentada a seguir), porque as duas são escritas com letras de um alfabeto.

Para representar foneticamente as palavras de uma língua, é preciso registrar todas as nuances de pronúncia. Por exemplo, a palavra BALDE, em português, teria muitas escritas diferentes, conforme a classe social e a região do país a que pertencem às pessoas que estiverem escrevendo. Na pesquisa realizada por Vitorino (1999) para o vocábulo balde, na codificação escrita, considerando-se os 30 (trinta) informantes, obteve-se $\mathrm{fj}$ = 20 e frj = 0,67. Argumenta-se, então, que "na escrita, o vocábulo balde é o que apresenta maior ocorrência $(0,67)$ da representação do fato fônico". (VITORINO, 1999, p. 115) e complementa: a) "o vocábulo balde, nas faixas etárias I e II, tem as mesmas frequências relativas $(0,60)$ e apresenta maior índice de semivocalização do /l/ em posição final de sílaba na codificação escrita; b) o vocábulo balde, na faixa etária III, apresenta maior 


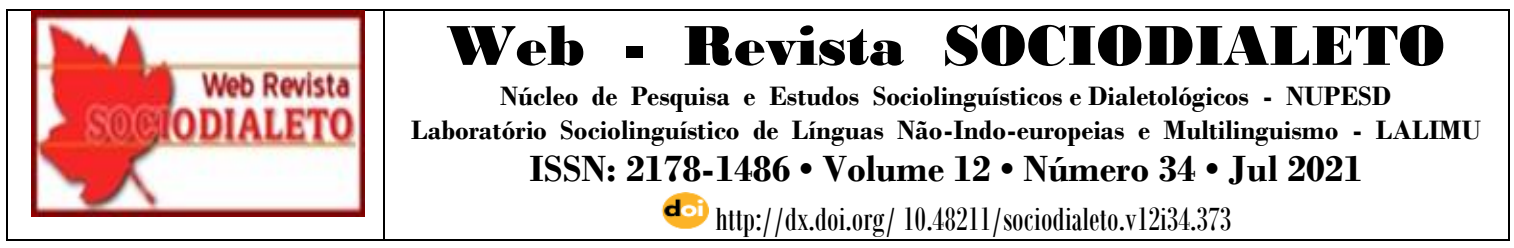

índice $(0,80)$ na recodificação escrita do fato fônico analisado". (VITORINO, 1999, p. 123)

É por este motivo que Cagliari costuma dizer que o alfabeto foi uma brilhante invenção que não deu certo (por causa da variação linguística); na opinião de Cagliari, o que salvou o alfabeto foi a invenção da ortografia.

O alfabeto fonético mais conhecido é o da Associação Internacional de Fonética, usado pelos linguistas do mundo inteiro para representar a maneira como as pessoas falam, não somente o que elas falam.

\subsection{1 .6 Escrita alfabética ortográfica}

Com a invenção do alfabeto e da escrita fonográfica, os usuários deste sistema esbarraram no problema da "variação linguística". Ficaria muito complicado para um usuário de uma região entender o que o outro tivesse escrito, se cada um deles escrevesse de maneira diferente. Isto destruiria a finalidade básica da escrita - que é possibilitar a leitura. Para resolver este problema, foi criada a ortografia.

Escrever ortograficamente significa escolher uma única forma para as palavras de uma língua, independente de quantas pronúncias diferentes possam estar ligadas a elas. A escolha de qual seja a forma ortográfica de cada palavra é, em geral, arbitrária. Às vezes, nem sequer corresponde a uma das possíveis pronúncias da palavra da língua.

Existe, na nossa sociedade, a crença de que a ortografia das palavras deve ser seguida rigorosamente, o que é um preconceito, já que a ortografia não representa a fala de ninguém, pois tem a função de anular a variação linguística, na escrita, no nível da palavra. O fato de a ortografia se aproximar mais da pronúncia das classes sociais mais privilegiadas deve-se, principalmente, ao fato de as pessoas pertencentes a estas classes sociais terem mais acesso à escolarização e, por causa disso, conhecerem a ortografia e policiarem a sua fala.

\subsection{Variação e mudança}




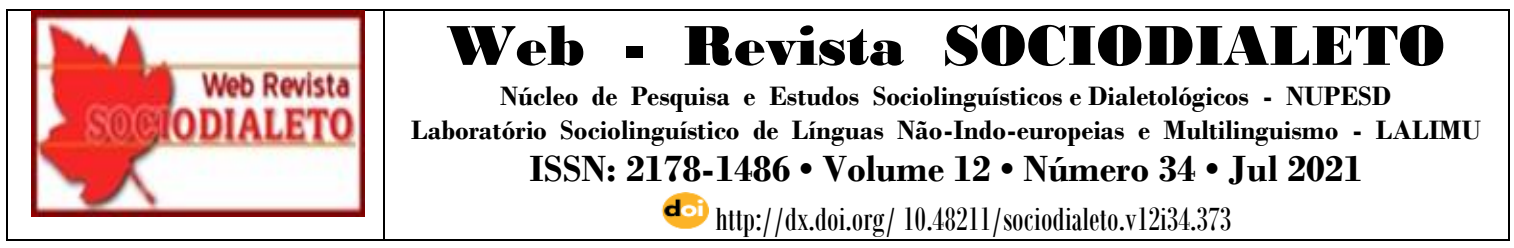

As variações e a mudança da língua têm sido estudadas pelos descritivistas desde o início das pesquisas linguísticas. As pesquisas mais recentes têm demonstrado que descrições estruturais da variação da língua são possíveis nas diferentes áreas da Fonologia, Morfologia, Semântica e Sintaxe e que é possível, também, classificar as variedades da fala, estando-se atento às suas características específicas. Estes procedimentos apenas não conseguem explicar as causas, nem as funções da variação da fala, pois os atos da fala não estão só atrelados ao uso das regras gramaticais, mas estão comprometidos também com o contexto e com o falante: sua interação social, sua classe social, se pertence à zona rural ou urbana, se deseja comunicar-se formal ou informalmente, sua faixa etária, escolaridade etc.

A abordagem social da língua, portanto, remete o linguista para além da descrição pura, buscando as razões de cada marca linguística, que funciona como senha. Essas razões são as variáveis históricas ou diacrônicas, geográficas ou espaciais e sociais.

Um breve comentário sobre as variantes linguísticas permite-nos estabelecer a seguinte divisão.

\subsection{Variantes Linguísticas}

\subsubsection{Variante histórica ou diacrônica}

O processo de mudança linguística não é tão simples como muitos acreditam. Uma variante para ser conhecida e reconhecida por uma comunidade, passa por um processo longo e demorado, isto porque uma variante em processo de adoção, para ser reconhecida e aceita, deverá ser usada por um grupo de prestígio socio políticoeconômico. Só aí ela passará a ser usada, ficando a variante anterior restrita às gerações mais antigas, passando a se constituir o que chamamos de arcaísmo.

\subsubsection{Variante geográfica ou espacial}

Variações relativas à pronúncia dos sons das palavras, às construções sintáticas e à seleção do vocabulário a ser usado em comunidades linguísticas espaciais devem-se ao 


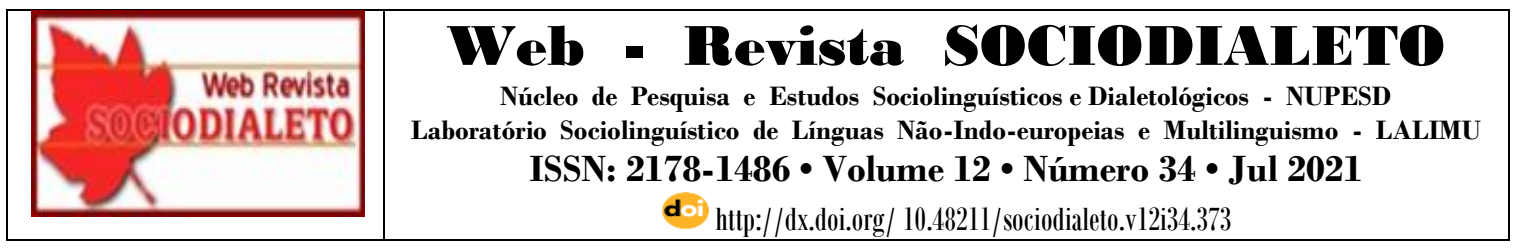

fato de que os nativos de uma mesma cidade, estado ou região, sob uma orientação de ordem cultural, política e econômica passam a constituir-se uma comunidade linguística mais limitada no bojo de uma maior e mais complexa, que é a nação.

\subsubsection{Variante social}

Não existe uma comunidade totalmente homogênea linguisticamente, isto porque, embora nascidos e criados numa área geograficamente restrita, os falantes apresentam variações na maneira de expressar-se. A semelhança entre as formas de expressão dependerá do grau de intercâmbio entre os falantes.

Logo, a capacidade verbal dos membros de uma comunidade linguística geograficamente homogênea é, a priori, adquirida no ambiente familiar e, num sentido mais amplo, na classe social, que se caracteriza por normas, padrões culturais e linguísticos diversos e distintos de outras comunidades.

É óbvio que o nível socioeconômico do indivíduo não é o único fator determinante de diversidade linguística, mas também, o grau de educação, faixa etária e o sexo do indivíduo.

\subsubsection{Variante estilística}

A adequação desta ou daquela forma a ser usada em diferentes situações vai depender da seleção a ser feita pelo indivíduo, dentre as formas que constitui o saber linguístico. Entra aqui o grau maior ou menor de reflexão sobre a forma de expressão a ser usada, que vai variar de acordo com o maior ou menor grau de formalidade da situação em que se encontra o indivíduo.

Logo, a variação estilística nada mais é que o resultado da adaptação da forma específica do ato verbal, relativa às circunstâncias em que se produz. O que equivale a que tantas são as variedades, quantas são as situações do dia a dia em que a atividade verbal se realiza. 


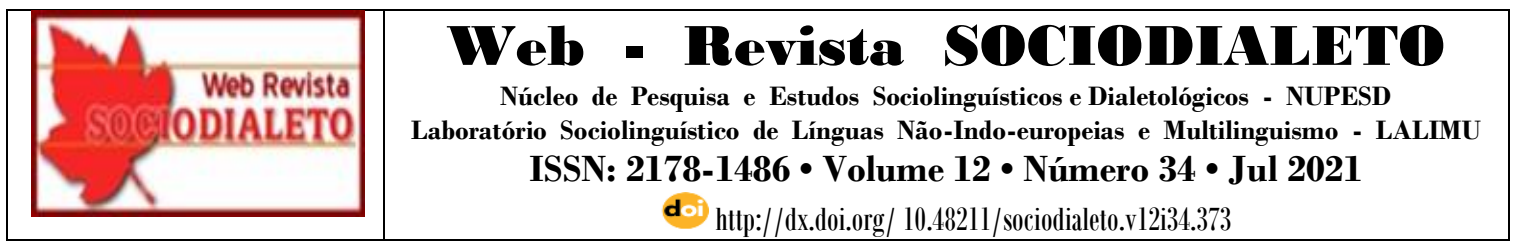

As noções de estilo formal e informal têm sido confundidas com as noções de língua escrita e falada. Obviamente, a modalidade escrita, como forma de expressão verbal, implica num certo grau de reflexão por parte do indivíduo, mais tempo para observar, corrigir, acrescentar informações etc. E, também, por falta de um contexto extralinguístico, vai exigir maior precisão e clareza, o que não ocorre na língua falada, onde há uma interação entre falante e ouvinte.

\section{CONSIDERAÇÕES FINAIS}

Ao fazer o estudo sincrônico da língua, ou seja, como ela é falada e escrita num determinado contexto, tempo histórico, "aqui e agora", o pesquisador constata que as variações são permitidas pelas regras subjacentes à estrutura/sistema linguístico, que funciona como salvaguarda da manutenção da língua.

Para o linguista, em termos de ensino da língua materna, a relação dialógica é fundamental, e a oralidade é o ponto de partida. É preciso que o/a professor/a, na sua caminhada junto ao seu alunado, parta do mais coloquial para o mais formal, considerando a bagagem do aluno no que diz respeito à linguística e à pragmática, ou seja, a competência comunicativa.

No momento em que a escola, lugar de produção e socialização do conhecimento, desconsidera o que o/a aluno/a fala e escreve e o/a reprova está passando o seu atestado de incompetência e obviamente não está cumprindo o seu papel de agente formador.

Diante das considerações apresentadas nesse artigo, achamos que o/a professor/a alfabetizador/a necessita de conhecimentos científicos daquilo com que trabalha. A linguística, ao longo do tempo, vem acumulando informações quanto às características da linguagem humana, suas funções, sua estrutura, que, compreendidas, podem funcionar como um instrumento eficiente para que o /a professor/a possa "distanciar-se" do fenômeno linguístico e discuti-lo, especular a respeito dele.

Finalmente, o que foi dito permite concluir que a formação dos educadores para atuar nos anos iniciais do ensino fundamental exige uma preparação que os leve a 


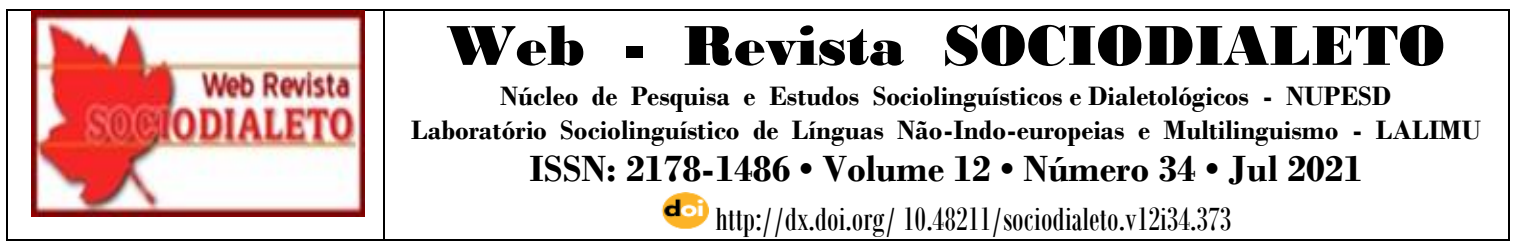

compreender todas as facetas (psicológica, psicolinguística, sociolinguística e linguística) e todos os condicionantes (sociais, culturais e políticos) do processo de alfabetização, que os leve a saber operacionalizar essas diversas facetas (sem desprezar os seus condicionantes) em métodos e procedimentos de preparação para a alfabetização e de alfabetização, em elaboração e uso adequados de materiais didáticos e, sobretudo, que os leve a assumir uma postura política diante das implicações ideológicas do significado e do papel atribuídos à alfabetização.

As informações oferecidas nesse artigo representam contribuição relevante ao trabalho de alfabetizadores e demais profissionais envolvidos na preparação de material didático para a alfabetização, na medida em que podem fornecer indicações sobre os problemas que, no processo de aquisição e domínio do sistema ortográfico, devem ser priorizados, e sobre como e quando devem ser abordados. Essas informações revelam-se ainda mais pertinentes, se utilizadas no exame do material didático que vem sendo produzido para a alfabetização. Essas falhas na seleção e ordenação do material de alfabetização têm, sem dúvida, grande parcela de responsabilidade pelo fracasso da escola na tarefa de alfabetizar.

\section{REFERÊNCIAS}

ABAURRE, M. O que revelam os textos espontâneos sobre a representação que faz a criança do objeto escrito? In: SEMINÁRIOS DO GEL. (1987, Campinas). Anais. Campinas: UNICAMP, 1987, p.129-135.

CAGLIARI, L. C. Alfabetização e ortografia. Educar, Curitiba, n. 20, p. 43-58. 2002. Editora UFPR.

CAGLIARI, L. C. Alfabetização \& Linguística. São Paulo: Scipione, 1989.

COSERIU, E. Do sentido do ensino da língua literária. Confluência - Revista do Instituto de Língua Portuguesa do Liceu Literário Português. Rio de Janeiro, n. 5, 1. ${ }^{\circ}$ semestre de 1993, p. 29-47, 1993.

COSERIU, E. Sincronia, Diacronia e História. Madrid: Gredos, 1973. São Paulo: Presença/Editora da USP, 1978.

DESBORDES, F. Écriture et ambigïté d'après lês textes théoriques latins. Modèles linguistiques, 5: (2), p. 13-37,1983. 


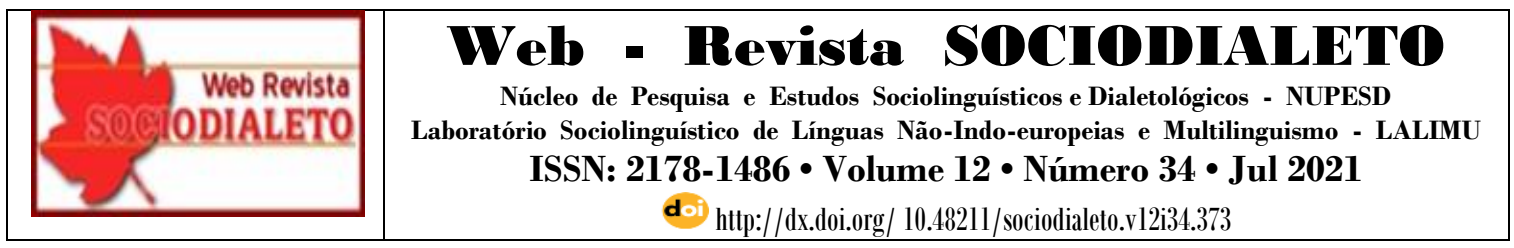

DINIZ, M. V. Métodos de alfabetização: pressupostos linguísticos. Dissertação de Mestrado. Belo Horizonte: UFMG, 1987. p. 6-30.

FARACO, C. A. Linguística histórica: uma introdução ao estudo da história das línguas. São Paulo: Parábola Editorial, 2005.

FERREIRO, E. Com todas as letras .São Paulo: Cortez, 1992.

FERREIRO, E. Reflexões sobre alfabetização. São Paulo: Cortez, 1989.

GERALDI, J. W. et al. Concepções de linguagem. In: O texto na sala de aula. Cascavel: Assoeste, 1984.

LABOV, W. Padrões sociolinguísticos. São Paulo: Parábola Editorial, 2008.

LABOV, W. Are Black and White vernaculars diverging? American Speech, 62 (1), 1987, p. $5-12$.

LABOV, W. Sociolinguistic patterns. Philadelphia, University Pennsylvania Press, 1972.

LABOV, W. Some souces of Reading problems for Negro speakers of non-standard english. In: FRAZIER, A. (org.). New Directions in Elementary English. Champaign: National Council of Teachers of English, 1967.

LABOV, W. The social Stratification of English in New York City. Washington, D. C.: Center for Applied Linguistics, 1966.

LABOV, W. stages in the acquisition of standard English. In: R. W. SHUY. Social Dialects and Language Learning. Champaign; National Council of teachers of English,1964.

LABOV,W. The social motivation of sound change. Word, 19:273 - 307,1963.

LEMLE, M. Guia teórico do alfabetizador. São Paulo: Ática, 1987.

LEMLE, M. \& NARO, A. J. Competências básicas do Português. Relatório final de pesquisa apresentado às instituições patrocinadoras MOBRAL e Fundação FORD. Rio de Janeiro. 1977.

LUCCHESI, D. Parâmetros Sociolinguísticos do português brasileiro. In: Revista da ABRALIN, vol.5, 1e 2, p. 83-112, dez. de 2006.

SANTOS, A. K. A. dos. Formação do educador alfabetizador e infância afrodescendente. In: SANTOS, A. K. Alves dos(org.). Alfabetização para a infância: perspectivas contemporâneas, vol I. Salvador: EDUFBA, 2010. cap. 5, p.93-117.

SAUSSURE, F. de. Curso de Linguística Geral. Tradução por Antônio Chelini, José Paulo Paes e Izidoro Blikstein. São Paulo: Cultrix, 1969.

SCHERRE, M. M. P. \& NARO, A. J. A concordância de sujeito no português do Brasil: um caso típico de variação inerente. In: HORA, D. da. (org.) Diversidade linguística no Brasil. João Pessoa, Ideia, 1997. p.93-114.

SILVA-CORVALÁN, C. Sociolingüística: teoria y análisis. Madri: Alhambra, 1989. 


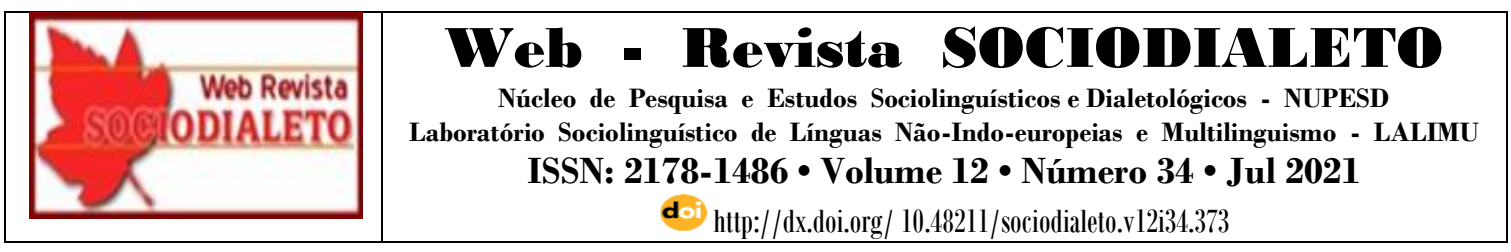

SILVA, M. B. da. Leitura, ortografia e fonologia. São Paulo: Ática,1981.

SILVA NETO, S. da. 1963[1951]. Introdução ao estudo da língua portuguesa no Brasil. 2. ed. Rio de Janeiro: INL

SOARES, M. Alfaletrar: toda criança pode aprender a ler e a escrever. São Paulo: Contexto, 2020.

SOARES, M. B. Alfabetização no Brasil: o estado do conhecimento. Brasília: Inep Reduc, 1989.

VITORINO, C. C.; SOUZA, C. M. B. de. A Sociolinguística e os estudos linguísticos: breves reflexões. In: Cairu em Revista: sociedade, educação, gestão e sustentabilidade., n. 13, ano 9, agosto 2020. Salvador-Bahia. p. 198-203.

VITORINO, C. C. Compreensão sociolinguística da fala e escrita de indivíduos alfabetizados na zona rural. 1999.169 f. Dissertação (Mestrado em Letras) - Programa de Pós-graduação em Letras e Linguística, Universidade Federal da Bahia, Salvador, 1999.

WEINREICH, LABOV, HERZOG. Fundamentos Empíricos para uma teoria da mudança linguística. Tradução de Marcos Bagno, São Paulo: Parábola Editorial, 2006.

Recebido em: 07/02/2021 | Aprovado em: 05/04/2021. 